Explaining Presidential Approval, 1993-2020:

\title{
An Examination of the Clinton, Bush, Obama and Trump Presidencies
}

\author{
Charles W. Ostrom, Jr. \\ Michigan State University \\ ostromc@msu.edu
}

\author{
Alon P. Kraitzman \\ Australian National University \\ alon.kraitzman@anu.edu.au \\ Brian Newman \\ Pepperdine University \\ brian.newman@pepperdine.edu
}

September 6, 2021 


\begin{abstract}
Can public support for recent presidents be explained by long-held findings in the presidential approval literature? The presidencies, of Clinton, George W. Bush, Obama, and Trump seem to counter the existing literature, suggesting that recent approval ratings have become disconnected from the political environment. We synthesize prior scholarship on the environmental connection, salience, and economic handling to develop a general model to evaluate approval during the 1992-2020 period. The model estimates show the environmental connection remains intact. Looking at these four presidents together, we find the public punished and rewarded presidents in a manner consistent with the long-held findings of the literature. Even though each of these four presidents served in unique circumstances, the foundation of the public's approval remained consistent. Our results point to an enduring environmental connection that holds presidents accountable for the conditions of the day.
\end{abstract}

Keywords: presidential approval; presidency; salience; economic approval; accountability 
The presidencies of Bill Clinton, George W. Bush, Barack Obama, and Donald Trump seem at odds with the basic findings of the expansive presidential approval literature (e.g., Mueller 1970; Kernell 1978; Ostrom and Simon 1985; MacKuen et al. 1992, see Gronke and Newman 2009 for a review). This literature has consistently concluded that as objective and perceived economic conditions improve or worsen, approval ratings rise or fall. After dramatic "rally" events, approval jumps briefly. When battle deaths increase, approval ratings fall. When the public harbors serious concerns about the president's leadership, as during major scandals, approval ratings drop. Yet, during the past four presidencies, the connections between these aspects of the political environment and approval ratings seem to have either atrophied or broken down entirely. According to recent studies, economic effects on approval have attenuated or disappeared in recent years (e.g., Eichenberg et al. 2006; Voeten and Brewer 2006; Donovan et al. 2019; Small and Eisinger 2020; Newport and Saad forthcoming; Singer 2021). Although scandals like Watergate and the Iran Contra affair led to double-digit drops in approval ratings (e.g., Kernell 1978; Ostrom and Simon 1985), scandals leading to Clinton's impeachment and Trump's first impeachment were followed by increases in approval. Rising U.S. battle deaths in Vietnam, Iraq, and Afghanistan led to deep declines in approval for Lyndon Johnson and George W. Bush (Mueller 1970; Eichenberg et al. 2006; Gelpi et al. 2006), but seemed to have little impact on Obama's approval, which was generally stable over time despite mounting battle deaths in Afghanistan. The central question for this inquiry is: can a general model, based on the existing literature, explain approval ratings for the past four presidents?

Explaining approval ratings for the past four presidents is important for three reasons. First, the possibility that the connection between the political environment and approval ratings, the "environmental connection", has broken down holds deep implications for presidential accountability, raising the possibility the public no longer punishes or rewards presidents for 
their failures and successes. This suggestion, for example, is front and center in a growing number of studies asking if approval of "Teflon Don" responded to scandals, policy flip-flops, or the economy (e.g., Darr et al. 2019; Donovan et al. 2019; McDonald et al. 2019). Trump's approval ratings seem entirely disconnected from the political environment as they moved less than any of his predecessors', stubbornly holding within a few points of 40 percent. The apparent unresponsiveness of Trump's approval has led observers (e.g., Economist 2019) to question whether anything in the political environment matters for approval ratings anymore.

Second, while an overarching goal of social science is to seek generalizable explanations, extant studies of these presidents suggest the determinants of approval ratings differ dramatically from president to president, precluding the possibility of a generalizable model. In this vein, some studies examine presidents in isolation or estimate different models for different presidents (e.g., Voeten and Brewer 2006; Ostrom Jr et al. 2018; Donovan et al. 2019), moving away from efforts to employ a generalizable model across multiple presidencies (e.g., Ostrom and Simon 1985; MacKuen et al. 1992). Substantively, prominent accounts of each presidency's approval ratings differ significantly from one another. For example, scholars argued that Clinton's approval ratings remained high in spite of impeachment largely because of a booming economy (e.g., Zaller 1998; Newman 2002). In contrast, studies argue the economy was virtually irrelevant for George W. Bush's approval ratings, which were driven primarily by battle deaths in Iraq and Afghanistan (e.g., Eichenberg et al. 2006; Voeten and Brewer 2006). Although battle deaths continued to mount during Obama's presidency, these deaths, the central driver of Bush's approval ratings, appeared to have no impact on Obama's largely stable approval ratings, while few things in the tumultuous political environment seemed to move Trump's approval. In sum, after the Clinton, Bush, Obama, and Trump presidencies it is unclear whether it is possible to employ a general model of presidential approval across presidencies. 
Third, aggregate approval ratings are politically consequential and, as such, are critical to understand. Approval ratings can alter presidents' policy proposals (Canes-Wrone 2006), their public statements about issues (Eshbaugh-Soha and Rottinghaus 2013), and their use of unilateral powers (Rottinghaus and Warber 2015). Approval ratings can also affect presidential success in Congress (e.g., Canes-Wrone and De Marchi 2002), attitudes toward the use of unilateral powers (e.g., Reeves and Rogowski 2016), and the success of the president's party in elections (e.g., Newman and Ostrom 2002; Sides and Vavreck 2014). Given the political significance of aggregate approval ratings, our analyses focus on the aggregate context, leaving for future research many important related group-level and individual-level questions.

Using prior scholarship, we build a synthetic model of approval ratings that acknowledges the importance of (1) four fundamental elements of the environmental connection (peace, prosperity, presidential leadership, and security), (2) issue salience (e.g., Edwards et al. 1995; Ostrom Jr et al. 2018; Cavari 2019), and (3) politically informed perceptions of the president's handling of the economy (e.g., Evans and Pickup 2010; Dickerson 2016; Cavari 2019). Synthesizing these three research strands provides a generalizable model with sensible estimates across these four presidencies. The results from this model provide two major substantive payoffs. First, they show the environmental connection remains in operation, though the connection is filtered by salience and political views and therefore variable over time. Second, the results provide an explanation for the dramatically different, often surprising paths of approval for these four presidencies. The results help us see, for example, why the economy provided much help to Clinton but not much to Bush, why casualties had a profound impact on Bush's approval but not Obama's, how impeachment actually did hurt both Clinton and Trump, and how 9/11 and COVID-19 had similar impacts. 


\section{Theoretical Foundations}

Our theoretical approach is to synthesize three important pillars of prior research into a single operationalized model: the environmental connection, issue salience, and the public's politically-charged assessments of the president's handling of the economy.

Environmental Connection. We begin with the well-established "environmental connection", the link between presidential approval and four important elements of the political environment, namely peace, prosperity, presidential leadership, and security. In addition to finding a link between economics and approval, whether economics is conceptualized as objective economic indicators (e.g., Kernell 1978; Ostrom and Simon 1985) or perceptions of the economy (MacKuen et al. 1992; Clarke and Stewart 1994; Norpoth 1996; Acevedo et al. 2017), many studies documented the negative effect long wars can have on approval, especially as U.S. battle deaths mount (e.g., Eichenberg et al. 2006; Gelpi et al. 2006). The public's desire for competent, ethical leadership from the president is well documented (e.g., Kinder 1986; Greene 2001; Newman 2003; Clifford 2018; see also Alesina, Rosenthal, et al. 1995; Duch and Stevenson 2008). Approval ratings track with public views of the extent to which the president gets things done and shares the public's values (Newman 2004), while the public punishes presidents when it has concerns about the president's leadership (e.g., during Watergate and the Iran-Contra affair; see e.g., Kernell 1978; Ostrom and Simon 1985).

Perceived threats to security come in many forms, including terrorism, crime, limited access to health care, immigration, and pandemics. At various times during the period of study, these threats have been highly salient and linked to approval ratings (e.g., Hetherington and Nelson 2003; Willer 2004; Kalmoe et al. 2019). In addition, most studies find dramatic events shape approval, including some extraordinary events like the $9 / 11$ attacks and a set of more ordinary, but nevertheless dramatic events (e.g., Newman and Forcehimes 2010). 
Although various studies cited above (and more) find evidence of a connection between these four elements of the political environment and approval ratings, most studies do not include all four elements in a single model. We believe that this is a result of the fact that in a single presidency all of the elements may not come into play. For example, the impact of war and security vary considerably over time. By looking at four presidencies together, it is possible to assess the impact of all relevant factors in the same model.

Salience. Since it first began to be used in political science, the notion of salience has been applied to denote a form of engagement with an issue and to capture what people attend to and care about (RePass 1971; Moniz and Wlezien 2020). Recent research has demonstrated that the four elements of the political environment just described have more impact on approval when they are salient (e.g., Edwards et al. 1995; Cavari 2019). Since issue salience changes over time, Edwards et al. (1995, p. 110, emphasis added) argue that "understanding presidential approval, then, requires identifying not only what issues Americans think about but also gauging the degree of salience Americans place on these issues. One cannot assume that people always judge the president by the same benchmarks." Edwards et al. (1995), along with many after them, find that the impact of a particular outcome on evaluations of the president varies with the salience of that outcome (e.g., Druckman and Holmes 2004; Ostrom Jr et al. 2018; Cavari 2019; see also Kelleher and Wolak 2006). As noted by Moniz and Wlezien (2020), media coverage of issues makes them more or less salient, which then moderates their impact on public evaluation of presidents.

Economic Handling. Rather than assuming the public simply responds mechanistically to economic conditions the same way over time, as most models using objective indicators implicitly do, some studies find the public forms assessments of the president's economic performance (i.e., economic handling), assessments that are affected by overall views of the president (e.g., Evans and Pickup 2010; Dickerson 2016). These assessments consist of, perhaps 
among other things, a combination of perceived economic conditions as well as the politicized views of the degree to which the president is responsible for those conditions and of what the president is doing to make things better. Political perspectives, including attitudes toward the overall job the president is doing, color perceptions of the economy, attributions of responsibility for economic conditions, and a host of other political attitudes (e.g., Bartels 2002; Bisgaard 2015). As such, the process of translating economic conditions into evaluations of the president's overall handling of the economy is a political process. ${ }^{1}$

The next section describes how we operationalized the synthetic model that incorporates the environmental connection, salience, and economic handling. We then estimate the model, which generates sensible estimates that comport nicely with extant research and show that the model with salience and economic handling outperforms models that ignore these elements. We use the estimates to show the environmental connection is intact and then to explain presidential approval by demonstrating how the impact of environmental factors changes over time and across presidencies and by examining the underpinnings of approval for each president.

\section{Operationalizing the Model}

We constructed a monthly model from January 1993 to December 2020 with two endogenous variables: presidential approval and economic handling. Tables A1 and A2 in Appendix A provide the definitions, measurement rules, and data sources for all of the variables used in this study, while Table B1 provides the summary statistics. Presidential approval is based on data from the Gallup poll. ${ }^{2}$ We created a monthly approval variable that averages all polls in the field at least one day during the month $(N=336)$.

\section{[INSERT FIGURE 1 HERE]}

Assessments of presidents' economic handling are based on the question "Do you approve or 
disapprove of the way [the incumbent] is handling the economy?". Since no polling organization asked the economic handling question in every month under study, we combined responses to this question from several organizations via Stimson's (1999) Dyad Ratios Algorithm. During the Clinton and Bush presidencies, the data came from Gallup and CBS/New York Times polls. During the Obama and Trump presidencies, we employed data from multiple polling organizations collected and posted on RealClearPolitics (RCP). ${ }^{3}$ Figure 1 displays the average monthly percentage of Americans who approved of the president's job performance and his handling of the economy from 1993-2020.

The overall approval model includes measures relating to prosperity, peace, leadership concerns, and both internal and external security. We measure prosperity's impact via perceptions of the president's handling of the economy, described more below. In terms of peace, we use the log of the number of US battle deaths in Iraq and Afghanistan (e.g., Eichenberg et al. 2006; Gelpi et al. 2006), restarting at zero for each president. As for leadership concerns, we assume the public is always ready to punish the president when it perceives clear leadership deficits. Therefore, when perceptions arise that there are problems in the president's leadership, approval should be lower in proportion to the public's leadership concerns.

We focus on two types of perceived security threats: external and internal. Perceived external threats include terrorism, natural disasters, and disease outbreaks. Perceived internal threats to the fabric of U.S. society include crime, immigration, and limited access to health care. We assume the public is always monitoring these potential threats and ready to adjust evaluations of the president in response to perceptions of the significance and magnitude of these threats. Therefore, variation in the impact of these variables comes from variation in their salience. Because external threats often lead to "rally-round-the-flag" effects, boosting approval, we expect approval to increase with heightened concern about external threats. In contrast, threats internal to the country are often perceived as at least partly owing to the 
president, suggesting heightened concern about these threats depresses approval.

We follow virtually every study of presidential approval by including two types of dramatic events: extraordinary and ordinary. Ostrom and Smith (1992, p. 132) argue that a few extraordinary events move approval to a "new equilibrium state" because of their dramatic and far-reaching consequences. ${ }^{4}$ We include two types of extraordinary events: existential threats (9/11 attacks and the COVID-19 pandemic) and impeachment trials. For both existential threats and impeachment, we include a dummy variable equaling 1 from the beginning of the event through the end the president's current term in office as we contend it takes a new election to fully integrate such extraordinary events into the political calculations. ${ }^{5}$ In addition to the "shock" of the aforementioned existential threats, we also hypothesize that the public pays attention to the number of deaths that result from the event leading to the shock. To measure this impact we use the log of the cumulative number of deaths resulting from the shock. This factor stays in place until the end of the president's current term.

We also include four types of ordinary political events for domestic (positive/negative) and international (positive/negative) events. To identify events, we used and updated Newman and Forcehimes's (2010) list of events (see Appendix Tables B2-B4).

The economic handling model includes overall approval, along with measures that capture retrospective and prospective evaluations of the economy. The first two economic indicators are derived from the Index of Consumer Sentiment (ICS). Higher values of the Current Index are expected to be associated with higher approval ratings. We also include the difference between the Current and Expected Indexes of the ICS to take into account prospective evaluations. When the Future Index is lower than the Current, we expect citizens to punish the incumbent in proportion to the difference. In addition, since approval is sensitive to the stock market (Fauvelle-Aymar and Stegmaier 2013; Newman and Otto 2021) we include the level 
of the S\&P 500 in terms of dollars per share. When the S\&P is high, we expect citizens to reward the president. The model also includes the existential threat and impeachment variables included in the overall approval model since these events could impact assessments of the president's handling of the economy. Finally, we include two types of ordinary economic events (positive/negative) using the same procedure we described above (see Appendix Table B5).

To measure salience, we follow various studies by using Gallup's standard Most Important Problem (MIP) item (e.g., McCombs and Zhu 1995; Edy and Meirick 2018; Cavari 2019, see also Wlezien 2005). We collapsed responses into categories appropriate to each variable type. ${ }^{6}$ We deviate from our use of the Most Important Problem data for the"salience" of the variable measuring the number of deaths from the existential shocks (i.e., 9/11 and Covid-19)

in order to connect the fear of death engendered by the actual deaths from the external shock. ${ }^{7}$ We weight each of our environmental variables by their salience (see Appendix Table A2). ${ }^{8}$ Appendix C provides a short discussion - along with a table and figure - that shows how salience has varied over the 28-year period under study.

\section{Specification, Identification, and Estimation}

Since we expect overall approval and economic handling to affect each other contemporaneously, we specify a simultaneous equation model with presidential approval and a president's handling of the economy as the two endogenous variables (see Equations 1 and 2 in Appendix D). ${ }^{9}$ In addition to the usual theoretical issues surrounding model specification, simultaneous equation models raise the issue of identification. We must consider two points when assessing the identification of an equation system. First, the order condition requires that one has at least as many excluded exogenous variables as there are included endogenous variables in each of the structural equations (Wooldridge 2015, p. 503). Since there are two endogenous vari- 
ables in each equation, the order condition requires that we exclude at least two exogenous variables from each equation. In the approval equation there are five excluded exogenous variables and two included endogenous variables. In the economic handling equation, there are 8 excluded exogenous variables and two included endogenous variables. Therefore, the order condition is satisfied. We address the second condition, the rank condition, empirically through the Kleibergen-Paap test for under-identification. In addition, we evaluate the issue of IV relevance by examining Shea's Partial R-Squared of excluded instruments.

Finally, there is a long history of dealing with statistical problems of serial correlation (e.g., Hibbs 1973) and heteroscedasticity (e.g., Gronke and Brehm 2002) in models of presidential approval. These problems can lead to overconfidence in the results. Given that we have simultaneous equations, the approach to dealing with serial correlation is somewhat different than in the context of estimating a single-equation approval model. We estimate model parameters via 2SLS and implement a heteroskedasticity- and autocorrelation-consistent (HAC) procedure, which provides robust standard errors in the face of these two statistical problems in the simultaneous equation context. ${ }^{10}$

The estimates are presented in Table 1. The Kleibergen-Paap test provides evidence that both equation systems are identified. ${ }^{11}$ We find strong support that the instrumental variables are relevant using Shea's Partial R-Squared test. ${ }^{12}$ In addition, we reject the null hypothesis that the specified endogenous regressors can actually be treated as exogenous. ${ }^{13}$ In short, there is clear evidence that both equations are identified, the IV estimates are solid, and the endogenous variables (Approval and Economic Handling) are endogenous.

\section{[INSERT TABLE 1 HERE]}

Before moving on, we note that the model in Table 1 outperforms alternative models that ignore salience and/or economic handling (see Appendix D for details and Table D-2 for 
the results). We find for both the approval and economic handling equations, in every case including salience and/or economic handling provides a better fit than ignoring salience and/or economic handling. In sum, the basic pillars of our model have strong empirical support.

\section{The Environmental Connection}

Given the empirical results from the previous section, our first task is to assess the presence of a consistent environmental connection which is the foundation of a general model of presidential approval. We turn to an examination of each of the structural equations.

\section{Economic Equation}

The overall fit for the Economic Handling equation is quite good, accounting for $90.1 \%$ of the variance with average error of 3.24. All but one of the variables in the Economic Handling equation (External Security Deaths) is statistically significant in the predicted direction. Presidential approval plays an important role in explaining economic handling with approximately $51 \%$ of the monthly approval rating being part of economic handling. This estimate supports the idea that evaluations of economic handling have a distinctly political component via the direct relationship with approval.

The three economic variables have a strong relationship with Economic Handling. The Current Index of ICS has a highly significant impact on Handling - the higher the index, the better the public views of economic handling. As predicted, the gap between Current and Future Expectations plays an important role - when the future looks worse than the present, assessments of Economic Handling decrease. Finally, there is a strong relationship between the performance of the stock market and the public's assessment of Economic Handling. Taken together, these variables add significantly to the explanation of Economic Handling.

As expected, given their disruption to the economy, existential threats had a negative impact of 3.8 points on Economic Handling. Impeachment was positively related to Economic 
Handling, increasing it by 8.5 points, a finding we return to below. Additionally, both positive and negative economic events have a statistically significant impact in the predicted direction on the public's assessment of how the president is handling the economy. Positive economic events tend to increase the public's assessment of economic handling by about 3.0 points while negative events will lower the assessment by about 1.7 points.

The state of the economy - as captured by the three economic variables - plays an important role in explaining Economic Handling. In addition, we find evidence that existential threats and impeachment directly impact economic handling. Finally, the political nature of the economic handling assessment is demonstrated by the role that current approval plays in accounting for the variation in Economic Handling.

\section{Approval Equation}

The overall fit for the Approval equation is likewise satisfactory, accounting for $92.1 \%$ of the variance with average error of 2.99. All of the variables are statistically significant in the predicted direction. There is a very strong relationship between Economic Handling and Approval in Table 1. The estimated coefficient suggests about $64 \%$ of the monthly economic handling assessment is part of the monthly approval level. The public's assessment of the president's handling of the economy is a significant and important determinant of approval ratings. Other estimates fit with our theoretical expectations and existing research. Salienceweighted battle deaths played an important role in presidential approval ratings as seen by the magnitude and significance of the estimated coefficient. In addition, Internal Security, External Security, and Leadership Concerns - each measured by monthly salience scores - all play a statistically significant role in explaining variations in presidential approval ratings. As

expected, Existential Threats (i.e., 9/11 and COVID-19) led to a direct and sustained increase in approval of approximately 7.7 points, while subsequent related deaths eroded approval. 
Unlike previous research, our results show that impeachment led to a direct and sustained monthly loss in approval of about 6.2 points for both Clinton and Trump for the duration of the term in which they are tried. This result is remarkable as it is the first time we know of that an approval model estimates a significant, substantial, and negative impeachment effect on approval. The effect covers two impeachments more than twenty years apart and demonstrates the anticipated negative impact that an impeachment trial has on a president's approval ratings.

Three of the four event variables were also statistically significant in the predicted direction - Positive Domestic, Negative Domestic, and Negative International - adding/subtracting 1.8 to 2.8 points to a monthly approval prediction.

Taken together, these results provide evidence supporting the presence of an environmental connection in our model of approval, though the connection is filtered by salience and political considerations. First, the economy plays a role across all four presidencies. Second, there is strong evidence that war has been a factor whenever there are significant battle deaths that are salient to the public. Finally, leadership concerns and political events - both ordinary and extraordinary - affect presidencies in predictable ways. The evidence, for this period in history, strongly supports the notion of an enduring environmental connection.

\section{The Impeachment Puzzle}

Before leaving the discussion of the environmental connection, it is worth noting how the two equation model accounts for the impeachment puzzle: why in two impeachments over 20 years apart did the president's approval ratings seemingly remain steady and even rise? The two structural equations, taken together, provide an explanation for the impeachment puzzle.

Clinton's high approval ratings during impeachment came as a surprise. As Zaller (1998, 182) put it, "no analyst of public opinion could have credibly predicted this outcome." Ed- 
wards (2000, p. 42) suggested the public's apparent willingness to separate Clinton's behavior from its approval marked a change in the public's approval calculus, saying "the public's low evaluation of the president as a person was nothing new ... What is new is the lack of weight people seem to give the president's integrity in their overall evaluations of his performance." Models of approval have generally found impeachment had no statistically significant effect (e.g., Smyth and Taylor 2003; Geys and Vermeir 2008; Newman and Forcehimes 2010) or a statistically significant positive effect (e.g., Geys 2010). There are similar accounts for Trump's first impeachment in the popular press (McCarthy 2019; Murray 2020).

Our answer to this puzzle lies in the reciprocal relationship between approval and economic handling. Our model differs from earlier models by taking into account the impact of Clinton's impeachment and Trump's first impeachment on views of each president's handling of the economy. We suspect that as the Lewinsky and Ukraine scandals unfolded and the Congress moved toward impeachment, two things happened that may have affected the public's assessment of the presidents' handling of the economy. First, public attention to politics increased. Second, both presidents focused on strongly favorable economic conditions. For both presidents, economic handling was at its highest levels of their presidencies when impeachment proceedings began. Consequently, more people may have been paying attention than normal and when they tuned in, they learned the economy was in very good shape (e.g., Zaller 1998; Erikson et al. 2000). For example, just days after the Lewinsky scandal broke, Clinton delivered his State of the Union address to a larger than average television audience. ${ }^{14}$ Clinton did not mention the scandal but spent over an hour lauding the robust economy and generally favorable state of the union (Zaller 1998). Along the same lines, Trump delivered the 2020 State of the Union Address the same week his impeachment trial ended, repeatedly showcasing the economy during a week when Fox News garnered the highest ratings of Trump's presidency to that point (e.g., Nakamura 2020; Orr 2020; Romans 2020; Katz 2020). Given 
these good economic times and the increased attention to politics (especially the economic good times) during the scandals, the public seems to have rewarded Clinton and Trump, as the economic handling model finds that impeachment boosted handling numbers by about 8 points, indirectly boosting overall approval. At the same time, the job approval model shows the direct impact of impeachment dropped approval by about 6.2 points. Thus, there is clear evidence that impeachment had a significant negative impact on both Clinton and Trump approval levels just as Watergate did with Nixon.

Appendix E provides a discussion of the reduced form of the structural equations in which each endogenous variable is expressed as a function of all of the exogenous variables in the entire model. Given that the coefficients for impeachment have opposite signs in the two equations, the net effect, as characterized by the reduced form, shows little if any impact for impeachment. Without including impeachment in both equations, it appears that impeachment had no impact whatsoever on approval (See Table E1). Models that ignore the positive impact of impeachment on economic handling run the risk of masking the negative impact impeachment had on these two presidents' overall approval. ${ }^{15}$

\section{Explaining Presidential Approval}

Our remaining contribution focuses on using the general model to provide a plausible explanation for the similarities and differences within the four presidencies since 1992. To augment our exploration of the similarities and differences in presidential approval for Clinton, Bush, Obama, and Trump, we offer four composite variables (see Appendix F), Economy, War, Security, Leadership Concerns, that provide a way to visually assess the direct impacts of the economy, war, leadership, and security as filtered through salience across the four presidencies.

Summary statistics for the four composite variables are presented in Table 2, broken down by presidency. These variables portray the contribution of each composite variable to the 
predicted value of approval for each presidency. Figure 2 provides a graphical characterization of each of the composite variables over the 28-year period under study.

\section{[INSERT TABLE 2 HERE]}

Table 2 and Figure F-1 show substantial swings in the impact of economic handling on predicted approval for each of the four administrations. For Clinton, the difference ranges from 23.0 and 47.8 - a range of nearly 25 points. The ranges for Bush, Obama, and Trump are 21,13 , and 11 respectively. The economy has played a major role in approval over the entire span, but the variation between the highs and lows has been dropping consistent with recent research (e.g., Donovan et al. 2019; Small and Eisinger 2020). Overall, the president's handling of the economy remains an important factor in explaining presidential approval.

Figure 2 also portrays the changing impact of war deaths, showing the radically different impact of War for Bush, Obama, and Trump. The number of battle deaths during the Bush and Obama administrations is similar. However, the salience of the war varied dramatically (see Table C1). Consequently, by the end of the Bush administration, the model estimates that war led to a 16.2 point drop in approval, consistent with other analyses of war's impact on Bush's approval (e.g., Gelpi et al. 2006; Eichenberg et al. 2006; Voeten and Brewer 2006). In contrast, when war was much less salient, a similar number of battle deaths during the Obama presidency only led to an estimated drop of 4.8 points. Finally, the deaths from war had a negligible impact on Trump's approval. These results illustrate Wlezien's (2005) finding that issue salience mostly reflects changes in the problem status of objective conditions.

The composite variable for Security, which includes the external security, external shock, external security death, and internal security variables, varies significantly over time as well. The negative values associated with Clinton are related to heightened concerns about crime 
during the 1990s. There is virtually no positive impact for either Clinton or Obama. There are, however, large impacts for Bush and Trump. In the aftermath of 9/11, there was a 14.4 point increase, a jump that comports with earlier studies of this unprecedented attack (e.g., Hetherington and Nelson 2003). The COVID-19 outbreak bears a close resemblance to the approval pattern following 9/11. As Figure 2 shows, like with 9/11, the model points to an initial increase of 12.5 points in Trump's approval although the initial surge is quickly dampened by the rise in highly salient COVID-related deaths.

The Leadership composite variable, which includes Leadership Concerns and Impeachment, likewise has varying impacts over time as well. Together these variables account for a maximum decrease of 11.5 points for Clinton during and after the impeachment trial, but not much impact on Bush's approval. Leadership Concerns proved a bigger drag on approval for Obama and especially Trump. At their worst, these concerns pushed Obama's approval downward by about 16.3 points and cost Trump about 24.4 points. It is likely that the fracturing and polarization following the 2008 general election and 2010 midterm election created important concerns for the public in terms of presidential leadership of the government (Abramowitz 2013; Thurber and Yoshinaka 2015). Regardless of party, presidents are being punished at the polls for this fracturing in the body politic.

It seems clear from Table 2 and Figure 2, therefore, that the environmental connection is alive and well across the 1993-2020 period. Figure 2 can also help us explain the contours of approval for each presidency individually. That is, the four composite variables provide a relatively simple way of seeing how the political environment, along with salience, affected approval within each of these four presidencies (see also Figure F1).

\section{[INSERT FIGURE 2 HERE]}

Figure 1 shows the Clinton presidency was marked by a gradual upward path for approval, 
remaining high in 1998 and 1999 during the Lewinsky scandal and impeachment. Various analyses concluded the public essentially ignored the scandal when evaluating Clinton's overall performance and focused on the economy (e.g., Zaller 1998; Kagay 1999; Andolina and Wilcox 2000). Our model suggests the booming economy was indeed a powerful and positive driver of Clinton's approval. Figure 2 shows Clinton gained more from the economy in the latter part of his tenure than any of the other presidents we analyze. In the last years of the 1990s, market returns, retrospective, and prospective views of the economy were well above average and views of Clinton's handling of the economy ranged from the high 60 s to the low 70s, their highest levels in the years we studied. Even though Clinton's approval was steady or even rising during and after 1998, the year the Lewinsky scandal broke, the leadership concerns line in Figure 2 shows he paid a substantial price for the lapses in leadership and impeachment, losing about 11 points in approval. Without these leadership concerns, the model predicts Clinton would have ended his term with historically high approval (perhaps in the mid 70s, consistent with Newman 2002). All in all, the panels in Figure 2 provides an indication that President Clinton was both rewarded for the outstanding economy and punished for leadership concerns. Clinton's approval highlights that it is a combination of rewards and punishments that determines the path of approval during the course of a presidency.

The Bush presidency provides a remarkably volatile situation in which three of the factors in Figure 2 - Economy, War, and Security - played a prominent role in determining monthly approval that ranged from 26 to 88 over the course of his eight years in office. Our results are consistent with scholarship on the Bush presidency (e.g., Eichenberg et al. 2006; Voeten and Brewer 2006). The 9/11 attacks immediately raised external security's salience to the public, boosting Bush's approval as noted above. In 2002 and 2003, security concerns slowly dissipated, with the war in Iraq becoming more salient in 2003 and 2004. By January of 2005, war was the most frequently cited MIP. Concern about the war grew in 2006 and peaked in 
early 2007, when about three times a many people were citing the war as MIP compared to the economy, the next highest category. During this period, the model estimates the war cost Bush about 16 points in approval, as depicted in the deep crater in the war panel of Figure 2. The decreasing salience of security, increasing salience of war, and growing battle deaths led to a long decline in approval during Bush's second term. To make matters worse for Bush, the slide into the Great Recession increased the economy's salience. In January of $200825 \%$ of the public named war and 25\% named the economy as MIP. For the rest of Bush's presidency the economy remained the most cited MIP, with $70 \%$ naming the economy as MIP by the time he left office. Bush's economic handling numbers feel from the 40s and 30s in 2007 to the 20s in 2008, leading to overall approval ratings in the 20 s by the end of his second term. Thus, the economy remained relevant even during Bush's presidency, to the degree that the public held it as salient (see Ostrom Jr et al. 2018). Had the economy remained at even average levels late in Bush's presidency, the model predicts his approval ratings would have been about 10 points higher. Bush's approval provides an indication of how changes in salience can alter the environmental connection and what happens when the magnitude of the various punishments associated with poor environmental conditions exceed the rewards.

Obama's approval ratings have not been studied as much as Clinton's or Bush's and much of the research has focused on the role of race and ethnicity (e.g., Abrajano and Burnett 2012) rather than the traditional drivers of approval. However, consistent with Donovan, et al. (2019), we find the economy played a smaller role in Obama's approval ratings than was the case for earlier presidents. As Obama inherited the Great Recession, his economic approval numbers were much stronger than Bush's, averaging $56 \%$ in his first year compared to $28 \%$ for Bush's last year in office. However, they decreased steadily over time, averaging only $41 \%$ his second year and 38\% his third year, dragging down Obama's job approval ratings. Then, as the long, slow recovery took hold, approval of his economic performance increased to the 
low 40s and then averaged just under $50 \%$ his last two years in office. However, the economy's salience declined during this period as well. In Obama's first term, an average of $57 \%$ cited the economy as most important, while the average dropped to $29 \%$ during his second term. Consequently, Figure 2 shows the economy lifted his approval ratings somewhat during the latter part of his presidency, but the declining salience of the economy limited his gains.

At the same time, leadership concerns grew, from an average of about $8 \%$ citing these concerns as most important in his first year to an average of $17 \%$ his second term (with a maximum of 34\%), as negotiations between Obama and congressional Republicans repeatedly broke down, often avoiding government shutdowns at the last minute by passing short-term deals that only temporarily delayed dealing with fundamental problems. As the figure shows, these concerns took a toll on Obama's approval, negating some of the gains from economic recovery. Thus, the economy's limited effect on Obama's approval seems to stem from both the lower salience of the economy during Obama's second term and the drag of leadership concerns. Again, we see the combination of punishment and reward. Similar to Clinton and Trump (as we shall see), if Obama had not faced growing concerns about leadership, the model predicts his approval ratings would have been about 10-15 points higher.

The Trump presidency was a tug of war between the positive economy and negative impact of leadership concerns. Contrary to fears that Americans no longer care about the economy (e.g., Economist 2019), the public rewarded Trump as the economy reached great heights (see also Newman and Otto 2021). Views of Trump's handling of the economy were consistently about 10 points higher than his overall approval rating. The public's reward is seen most clearly by comparing the economy line in Figure 2 across presidencies. The impact of the economy was more positive for Trump than for Obama on average and roughly equal to that of the early Bush years. Clinton was rewarded for the economy more than Trump because Clinton's economic handling numbers were higher than Trump's (averaging 70\% during 1998- 
2000, compared to a $50 \%$ average during Trump's presidency). Contrary to contemporary accounts, the public rewarded Trump for economic successes. Trump's primary problem with respect to the economy was too much competition from other problem areas for the public to fully focus on the economy.

Leadership concerns had a dramatic impact on Trump's approval, negating much of the economy's boost. Despite fears that Trump really could shoot someone without losing support (as he claimed), public concerns about his leadership took a toll, consistent with Darr, et. al (2019). Concern about leadership was much higher for Trump than for Clinton, with an average of $30 \%$ of the public citing leadership concerns as MIP during Trump's presidency compared to an average of about $10 \%$ during the Lewinsky scandal and impeachment for Clinton. If Trump had even Obama-levels of leadership concerns, the model predicts his approval could have been about 6-8 points higher.

During the last year of Trump's presidency, COVID-19 hit the world and the US with a vengeance. As expected of an external threat, the public initially rallied, boosting Trump's approval. However, highly salient deaths resulting from COVID-19 infections generated a dampening of the overall increase. In sum, Trump did not reap the full approval benefits from the pandemic as a normal president would have. Instead because of the number and salience of the deaths from COVID-19, Trump's surge disappated quickly.

Rather than "Teflon Don", Figure 2 indicates Trump was consistently caught between two potent forces, the economy and leadership concerns, that were pulling in opposite directions with similar intensity. The result was an aggregate approval rating with a historically low mean over the course of Trump's presidency. 


\section{Conclusions}

The presidencies of Bill Clinton, George W. Bush, Barack Obama, and Donald Trump seem to challenge the basic findings of the long and deep presidential approval literature, raising the question: how well can the existing literature explain the approval ratings of the past four presidents? This question poses a challenge to scholars' goals of reaching generalizable explanations of one of the most politically consequential time series and calls into question whether the public has stopped holding presidents accountable for important conditions in the political environment.

We find synthesizing prior scholarship emphasizing (1) the political environment, (peace, prosperity, effective/ethical leadership, and security), (2) issue salience, and (3) politically informed perceptions of the president's handling of the economy provides two benefits. First, our results demonstrate a nuanced, but intact environmental connection. The public has been punishing and rewarding presidents, but in a way that reflects its changing concerns and politically informed assessments of the president's economic performance. Second, the results convey an explanation for public approval of four seemingly disparate presidencies within the context of a single model.

What do our results tell us about the public's willingness to reward and punish the president for environmental conditions? First, peace, prosperity, security, and leadership still matter, though in a more variable way than earlier studies assumed. Finding that each of these elements of the political environment had little impact on approval over some period of time is important (e.g., Eichenberg et al. 2006; Voeten and Brewer 2006; Donovan et al. 2019). However, such findings do not mean the environment is irrelevant; they simply reflect variation in the public's attention to the most important problems of the day. Second, shifting salience makes the consistency of the environmental connection difficult to see, especially 
when individual presidencies are studied in isolation. For example, some analyses of the Bush presidency concluded that the economy had no effect. Our results suggest that Bush got credit for a positive economy in the middle of his presidency, but that boost in approval was limited by relatively low concern about the economy and overwhelmed by increasing concern about the war in Iraq as battle deaths mounted.

Here we see the value of more general models. Studying individual presidencies, focusing too much on one or two environmental connections to the neglect of others, or ignoring changes in salience can lead to conclusions that the environmental connection is severed when in reality a particular element of the environment may be exerting less impact than at other times or that impact is overwhelmed by the impact of another highly salient element. When we look at these four presidents together, taking into account the main aspects of the political environment, allowing salience to vary and overall views of the president to color views of the president's economic performance, we find the public punished and rewarded presidents consistently.

Near the end of the article that spawned the study of presidential approval, Mueller (1970) included a section called "The Eisenhower Phenomenon." The section was an effort to detail reasons why President Eisenhower's approval was not susceptible to the same dynamics as that of Truman and Johnson. We have seen similar arguments in studies of Clinton, Bush, Obama, and Trump. As our results show, the public actually did punish Clinton and Trump for impeachment, did reward Bush, Obama, and Trump for economic gains, and did punish Clinton, Obama, and Trump for leadership deficits. The magnitude of these punishments and rewards varied over time and the punishments and rewards sometimes occurred simultaneously (and hence offset one another), making it appear the public is immovable as aggregate approval stayed relatively stable. Our results make clear that each of these four presidents served in unique circumstances but the foundation of the public's approval remained consistent. Returning to our central motivating question: we can explain these four presidents' approval 
ratings and do so with a general model that points to an enduring environmental connection that holds presidents accountable for the conditions of the day.

\section{Notes}

1. Some models of presidential approval include economic handling as an exogenous variable (e.g., Cavari 2019; McAvoy 2006) but do not allow these perceptions to be driven in part by overall views of the president. We construct a synthetic model that allows for the possibility of an endogenous relationship between approval and economic handling. Cavari, in his work, has dismissed this through testing but we feel that the possibility of endogeneity provides an interesting component to approval models.

2. http://www.gallup.com/poll/124922/presidential-job-approval-center.aspx accessed May 6, 2021.

3. https://www.realclearpolitics.com/epolls/other/president_trump_job_approval_economy6182.html accessed July 20, 2021.

4. The authors go on to observe: “. . . extraordinary events such as Watergate or the Iran-Contra affair shook citizens' faith in the authority of presidents Nixon and Reagan, respectively, thus shifting the approval equilibrium downward. These equilibrium shocks occur because extraordinary events cause fundamental changes in citizens' views about the ability of the president to provide expected outcomes."

5. The second impeachment of President Trump took place in January 2021 which is outside the scope of our data set.

6. Salience of the economy is based on ("economy in general," "unemployment/jobs," and "High cost of living/inflation"), external threat ("Terrorism," "Diseases/COVID-19," and "Natural Disaster"), internal security ("Crime," "Healthcare/Hospitals/Cost of Healthcare," and "Immigration/Illegal 
aliens"), war ("War"), and leadership ("Poor leadership", "Corruption", "Abuse of power"). Unfortunately, Gallup combines several categories ("Dissatisfaction with government, Congress, politicians") together, not all of which may be directly relevant to the president in the public's mind. However, we suspect that in many cases concern about any of these categories may indicate at least some concern about presidential leadership. The president is the focal point of the federal system, so generalized dissatisfaction with government and politicians may well fall at least partly on the president. Ultimately, we decided to include this category in our measurement of concerns about presidential leadership thinking we would induce more measurement error if we excluded the category than if we included it.

7. As an indication of salience we use the percentage of "Very Worried" responses to the following questions: (for 9/11) "How worried are you that you or someone in your family will become a victim of terrorism - very worried, somewhat worried, not too worried or not worried at all?" (for Covid-19) "How concerned Americans say they are that they, someone in their family or someone else they know will become infected with the coronavirus".

8. We coded the economic measures so that higher values are more positive conditions. We expect the public to punish presidents more when conditions are less positive and more salient. Therefore, we weighted the economic variables by (100 minus MIP) so low numbers indicate highly salient unfavorable conditions.

9. We employ a DF-GLS test for a unit root. The null hypothesis of a unit root is rejected for Presidential Job Approval at 5\% level for lags 1-8 and at the 8\% level for Economic Handling. This test supports the alternative hypothesis that both series are stationary around a mean.

10. We utilize the Bartlett kernel and the Newey-West procedure for bandwidth selection

11. The $\chi^{2}$ value for the underidentification test for the Approval Equation is 27.71 with 5 df while the chi-square value for Economic Handling Equation is 22.64 with 8 degrees of freedom. The two equation model satisfies the test for having sufficient rank. 
12. The F-test results from Shea's Partial R-Squared test for the first stage IV estimates are as follows: Approval Equation — F (5, 319) = 35.09; Economic Handling Equation - F (8, 319) = 23.83.

13. The $\chi^{2}$ results with one degree of freedom are $9.20(\mathrm{p}=.002)$ for Approval Equation and 7.41 $(\mathrm{p}=.007)$ for the Economic Handling Equation. Therefore, we reject the null hypothesis in each instance.

14. see https://www. washingtonpost.com/lifestyle/style/more-than-38-million-watch-obamasstate-of-the-union-address/2012/01/25/gIQAH13PRQ_story.html.

15. To see this, note that directly estimating the reduced form of the approval model without economic handling estimates no negative effect of impeachment on approval and hence misses an important nuance in the public's punishment of presidents caught in impeachment. 


\section{References}

Abrajano, Marisa, and Craig M Burnett. 2012. "Polls and Elections: Do Blacks and Whites See Obama through Race-Tinted Glasses? A Comparison of Obama's and Clinton's Approval Ratings." Presidential Studies Quarterly 42 (2): 363-375.

Abramowitz, Alan I. 2013. "The Electoral Roots of A merica's Dysfunctional Government." Presidential Studies Quarterly 43 (4): 709-731.

Acevedo, Delia N, Carlie Fogleman, and Joseph Daniel Ura. 2017. "Peasants and bankers: Education, consumer sentiment, and presidential approval." Presidential Studies Quarterly $47(2): 230-244$.

Alesina, Alberto, Howard Rosenthal, et al. 1995. Partisan politics, divided government, and the economy. Cambridge University Press.

Andolina, Molly W, and Clyde Wilcox. 2000. "Public opinion: the paradoxes of Clinton's popularity." The Clinton Scandals and the Future of American Government: 177-94.

Bartels, Larry M. 2002. "Beyond the running tally: Partisan bias in political perceptions." Political Behavior 24 (2): 117-150.

Bisgaard, Martin. 2015. "Bias will find a way: Economic perceptions, attributions of blame, and partisan-motivated reasoning during crisis." The Journal of Politics 77 (3): 849-860.

Canes-Wrone, Brandice. 2006. Who Leads Whom?: Presidents, Policy, and the Public. University of Chicago Press.

Canes-Wrone, Brandice, and Scott De Marchi. 2002. "Presidential approval and legislative success." The Journal of Politics 64 (2): 491-509.

Cavari, Amnon. 2019. "Evaluating the President on Your Priorities: Issue Priorities, Policy Performance, and Presidential Approval, 1981-2016." Presidential Studies Quarterly 49 (4): 798-826. 
Clarke, Harold D, and Marianne C Stewart. 1994. "Prospections, retrospections, and rationality: The" bankers" model of presidential approval reconsidered." American Journal of Political Science: 1104-1123.

Clifford, Scott. 2018. "Reassessing the structure of presidential character." Electoral Studies $54: 240-247$.

Darr, Joshua P, Nathan P Kalmoe, Kathleen Searles, Mingxiao Sui, Raymond J Pingree, Brian K Watson, Kirill Bryanov, and Martina Santia. 2019. "Collision with Collusion: Partisan Reaction to the Trump-Russia Scandal." Perspectives on Politics 17 (3): 772787.

Dickerson, Bradley. 2016. "Economic perceptions, presidential approval, and causality: The moderating role of the economic context." American Politics Research 44 (6): 1037-1065.

Donovan, Kathleen, Paul M Kellstedt, Ellen M Key, and Matthew J Lebo. 2019. "Motivated reasoning, public opinion, and presidential approval." Political Behavior: 1-21.

Druckman, James N, and Justin W Holmes. 2004. "Does presidential rhetoric matter? Priming and presidential approval." Presidential Studies Quarterly 34 (4): 755-778.

Duch, Raymond M, and Randolph T Stevenson. 2008. The economic vote: How political and economic institutions condition election results. Cambridge University Press.

Economist. 2019. "American Voters Don't Care About the Economy" (May 23). Accessed April 15, 2020.

Edwards, George C. III. 2000. "Campaigning Is Not Governing-Bill Clinton's Rhetorical Presidency." In The Clinton Legacy, edited by Colin Campbell and Bert A. Rockman, 33-47. Chatham, N.J.: Chatham House.

Edwards, George C. III, William Mitchell, and Reed Welch. 1995. "Explaining presidential approval: The significance of issue salience." American Journal of Political Science: 108134. 
Edy, Jill A., and Patrick C. Meirick. 2018. "The Fragmenting Public Agenda: Capacity, Diversity, and Volatility in Responses to the 'Most Important Problem' Question." Public Opinion Quarterly 82 (4): 661-685.

Eichenberg, Richard C, Richard J Stoll, and Matthew Lebo. 2006. "War president: The approval ratings of George W. Bush." Journal of Conflict Resolution 50 (6): 783-808.

Erikson, Robert S, Michael B MacKuen, and James A Stimson. 2000. "Bankers or peasants revisited: economic expectations and presidential approval." Electoral Studies 19 (2-3): $295-312$.

Eshbaugh-Soha, Matthew, and Brandon Rottinghaus. 2013. "Presidential position taking and the puzzle of representation." Presidential Studies Quarterly 43 (1): 1-15.

Evans, Geoffrey, and Mark Pickup. 2010. "Reversing the Causal Arrow: The Political Conditioning of Economic Perceptions in the 2000-2004 U.S. Presidential Election Cycle." The Journal of Politics 72 (4): 1236-1251.

Fauvelle-Aymar, Christine, and Mary Stegmaier. 2013. "The stock market and US presidential approval." Electoral Studies 32 (3): 411-417.

Gelpi, Christopher, Peter D Feaver, and Jason Reifler. 2006. "Success matters: Casualty sensitivity and the war in Iraq."

Geys, Benny. 2010. "Wars, presidents, and popularity: The political cost (s) of war re-examined." Public Opinion Quarterly 74 (2): 357-374.

Geys, Benny, and Jan Vermeir. 2008. "Taxation and presidential approval: separate effects from tax burden and tax structure turbulence?" Public Choice 135 (3): 301-317.

Greene, Steven. 2001. "The role of character assessments in presidential approval." American Politics Research 29 (2): 196-210.

Gronke, Paul, and John Brehm. 2002. "History, heterogeneity, and presidential approval: a modified ARCH approach." Electoral Studies 21 (3): 425-452. 
Gronke, Paul, and Brian Newman. 2009. "Public Evaluations of Presidents." The Oxford Handbook of the American Presidency: 232-253.

Hetherington, Marc J, and Michael Nelson. 2003. "Anatomy of a rally effect: George W. Bush and the war on terrorism." PS: Political Science \& Politics 36 (1): 37-42.

Hibbs, Douglas A. 1973. "Problems of statistical estimation and causal inference in time-series regression models." Sociological methodology 5:252-308.

Kagay, Michael R. 1999. "Presidential address: Public opinion and polling during presidential scandal and impeachment." The Public Opinion Quarterly 63 (3): 449-463.

Kalmoe, Nathan P, Raymond J Pingree, Brian Watson, Mingxiao Sui, Joshua Darr, and Kathleen Searles. 2019. "Crime News Effects and Democratic Accountability: Experimental Evidence From Repeated Exposure in a Multiweek Online Panel." International Journal of Public Opinion Research 31 (3): 506-527.

Katz, A.J. 2020. "State of the Union and Impeachment Trial Help FoxNews to Highest-Rated Week Since 2016 Election." AdWeek.

Kelleher, Christine A, and Jennifer Wolak. 2006. "Priming presidential approval: The conditionality of issue effects." Political Behavior 28 (3): 193-210.

Kernell, Samuel. 1978. "Explaining presidential popularity." American Political Science Review $72(2): 506-522$.

Kinder, Donald R. 1986. Presidential Character Revisited. S. 233-255 in: Richard R. Lau und David O. Sears (Hg.): Political Cognition.

MacKuen, Michael B, Robert S Erikson, and James A Stimson. 1992. "Peasants or bankers? The American electorate and the US economy." American Political Science Review 86 (3): 597-611.

McAvoy, Gregory E. 2006. "Stability and change: The time varying impact of economic and foreign policy evaluations on presidential approval." Political Research Quarterly 59 (1): $71-83$. 
McCarthy, Justin. 2019. "Trump Approval Inches Up, While Support for Impeachment Dips." Gallup. December.

McCombs, Maxwell, and Jian-Hua Zhu. 1995. "Capacity, Diversity, and Volatility of the Public Agenda: Trends from 1954-1994." Public Opinion Quarterly 59 (4): 495-525.

McDonald, Jared, Sarah E Croco, and Candace Turitto. 2019. "Teflon Don or Politics as Usual? An Examination of Foreign Policy Flip-Flops in the Age of Trump." The Journal of Politics 81 (2): 757-766.

Moniz, Philip, and Christopher Wlezien. 2020. "Issue Salience and Political Decisions." In Oxford Research Encyclopedia of Politics.

Mueller, John E. 1970. "Presidential Popularity from Truman to Johnson 1." American Political Science Review 64 (1): 18-34.

Murray, Mark. 2020. “NBC/WSJ poll: Country remains divided over Trump's impeachment trial." NBC News. February.

Nakamura, David. 2020. "Trump paints strong economy as vindication as he tries to move past impeachment." The Washington Post.

Newman, Brian. 2002. "Bill Clinton's approval ratings: The more things change, the more they stay the same." Political Research Quarterly 55 (4): 781-804.

—. 2003. "Integrity and presidential approval, 1980-2000." Public Opinion Quarterly 67 (3): $335-367$.

— 2004. "The Polls: Presidential Traits and Job Approval: Some Aggregate-Level Evidence." Presidential Studies Quarterly 34 (2): 437-448.

Newman, Brian, and Andrew Forcehimes. 2010. "'Rally Round the Flag” Events for Presidential Approval Research." Electoral Studies 29 (1): 144-154.

Newman, Brian, and Charles Ostrom. 2002. "Explaining Seat Changes in the US House of Representatives, 1950-98." Legislative Studies Quarterly 27 (3): 383-405. 
Newman, Brian, and Amber Otto. 2021. "The Economy and Events Still Matter (At Least a Little): Partisans' Presidential Approval in the Trump Era." Presidential Studies Quarterly 51 (4): FirstView.

Newport, Frank, and Lydia Saad. Forthcoming. "Presidential Job Approval." Public Opinion Quarterly: 1-19.

Norpoth, Helmut. 1996. "Presidents and the prospective voter." The journal of Politics 58 (3): $776-792$.

Orr, Gabby. 2020. "Trump's answer to impeachment? The economy.” Politico.

Ostrom Jr, Charles W, Alon P Kraitzman, Brian Newman, and Paul R Abramson. 2018. "Polls and Elections: Terror, War, and the Economy in George W. Bush's Approval Ratings: The Importance of Salience in Presidential Approval." Presidential Studies Quarterly 48 (2): $318-341$.

Ostrom, Charles W, and Dennis M Simon. 1985. "Promise and performance: A dynamic model of presidential popularity." American Political Science Review 79 (2): 334-358.

Ostrom, Charles W, and Renee M Smith. 1992. "Error correction, attitude persistence, and executive rewards and punishments: A behavioral theory of presidential approval." Political Analysis 4:127-183.

Reeves, Andrew, and Jon C Rogowski. 2016. "Unilateral powers, public opinion, and the presidency." The Journal of Politics 78 (1): 137-151.

RePass, David E. 1971. "Issue salience and party choice." American Political Science Review 65 (2): 389-400.

Romans, Christine. 2020. "As impeachment captures attention, Trump tries to shift focus to the economy." CNN.

Rottinghaus, Brandon, and Adam L Warber. 2015. "Unilateral Orders as Constituency Outreach: Executive Orders, Proclamations, and the Public Presidency." Presidential Studies Quarterly 45 (2): 289-309. 
Sides, John, and Lynn Vavreck. 2014. The gamble: Choice and chance in the 2012 presidential election. Princeton University Press.

Singer, Matthew. 2021. "It's NOT the economy when people are dying: accountability for household economic and health outcomes during the pandemic." Journal of Elections, Public Opinion, and Parties 31 (sup1): 155-166.

Small, Raphael, and Robert M Eisinger. 2020. "Whither Presidential Approval?" Presidential Studies Quarterly 50 (4): 845-863.

Smyth, David J, and Susan Washburn Taylor. 2003. "Presidential popularity: what matters most, macroeconomics or scandals?" Applied Economics Letters 10 (9): 585-588.

Thurber, James A, and Antoine Yoshinaka. 2015. American gridlock: The sources, character, and impact of political polarization. Cambridge University Press.

Voeten, Erik, and Paul R Brewer. 2006. "Public opinion, the war in Iraq, and presidential accountability." Journal of Conflict Resolution 50 (6): 809-830.

Willer, Robb. 2004. "The effects of government-issued terror warnings on presidential approval ratings." Current research in social psychology 10 (1): 1-12.

Wlezien, Christopher. 2005. "On the salience of political issues: The problem with 'most important problem'." Electoral studies 24 (4): 555-579.

Wooldridge, Jeffrey M. 2015. Introductory econometrics: A modern approach. Nelson Education.

Zaller, John R. 1998. "Monica Lewinsky's contribution to political science." PS: Political Science \& Politics 31 (2): 182-189. 


\section{Tables}

Table 1: Estimates of Presidential Job Approval and Economic Handling

\begin{tabular}{|c|c|c|c|c|c|}
\hline & & Coef. & Robust S.E. & Z-score & $\mathrm{P}$-value \\
\hline \multirow{17}{*}{ 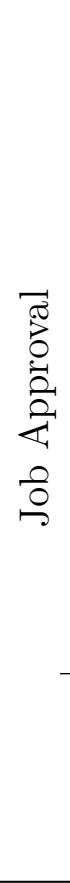 } & Economic Handling & 0.638 & 0.0362 & 17.640 & 0.000 \\
\hline & Battle Deaths & -11.784 & 0.754 & -16.640 & 0.000 \\
\hline & Internal Security & -0.099 & 0.030 & -3.230 & 0.001 \\
\hline & External Security & 0.234 & 0.055 & 4.250 & 0.000 \\
\hline & Existential Threat & 7.748 & 1.123 & 6.300 & 0.000 \\
\hline & Existential Death & -5.617 & 1.148 & -4.890 & 0.000 \\
\hline & Leadership Concerns & -0.479 & 0.030 & -15.910 & 0.000 \\
\hline & Impeachment & -6.217 & 0.942 & -6.600 & 0.000 \\
\hline & Positive International & 1.871 & 0.595 & 3.140 & 0.002 \\
\hline & Negative International & -2.797 & 0.644 & -4.340 & 0.000 \\
\hline & Positive Domestic & 1.887 & 0.550 & 3.430 & 0.001 \\
\hline & Negative Domestic & -2.814 & 0.437 & -6.44 & 0.000 \\
\hline & Constant & 28.136 & 1.953 & 14.400 & 0.000 \\
\hline & $R^{2}$ & 0.921 & & & \\
\hline & RSME & 2.999 & & & \\
\hline & AIC & 1717.523 & & & \\
\hline & BIC & 1757.145 & & & \\
\hline \multirow{15}{*}{ 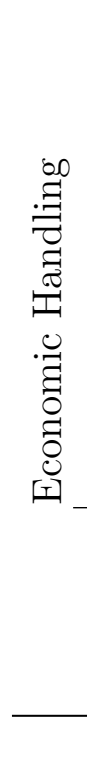 } & Job Approval & 0.510 & 0.039 & 13.020 & 0.000 \\
\hline & ICS: Current & 0.233 & 0.035 & 6.710 & 0.000 \\
\hline & ICS: Future - Current & -0.573 & 0.101 & -5.680 & 0.000 \\
\hline & S\&P 500 & 0.229 & 0.060 & 3.790 & 0.000 \\
\hline & Existential Threat & -3.869 & 1.223 & -3.160 & 0.002 \\
\hline & Existential Death & -2.467 & 1.710 & -1.440 & 0.149 \\
\hline & Impeachment & 8.535 & 1.270 & 6.720 & 0.000 \\
\hline & Positive Economic & 3.012 & 1.288 & 2.340 & 0.019 \\
\hline & Negative Economic & -1.708 & 0.599 & -2.850 & 0.004 \\
\hline & Constant & 11.098 & 2.077 & 5.340 & 0.000 \\
\hline & $R^{2}$ & 0.901 & & & \\
\hline & RSME & 3.241 & & & \\
\hline & AIC & 1706.641 & & & \\
\hline & BIC & 18014.812 & & & \\
\hline & $N$ & 336 & & & \\
\hline
\end{tabular}


Table 2: Impact of Composite Variables by President

\begin{tabular}{lrrrrrrrr} 
Composite & \multicolumn{2}{c}{ Clinton } & \multicolumn{2}{c}{ Bush } & \multicolumn{2}{c}{ Obama } & \multicolumn{2}{c}{ Trump } \\
Variables & $\min$ & $\max$ & $\min$ & $\max$ & $\min$ & $\max$ & $\min$ & $\max$ \\
\hline Economy & 23.0 & 47.8 & 18.4 & 38.8 & 20.2 & 33.6 & 26.1 & 38.4 \\
War & 0.0 & 0.0 & -16.2 & 0.0 & -4.8 & 0.0 & -0.5 & 0.0 \\
Security & -8.3 & 0.9 & -1.8 & 14.4 & -2.6 & 2.7 & -3.5 & 12.5 \\
Leadership & -11.5 & 0.0 & -6.2 & -1.0 & -16.3 & -1.4 & -24.4 & -10.5
\end{tabular}




\section{Figures}

Figure 1: Public Evaluation of Clinton/Bush/Obama/Trump

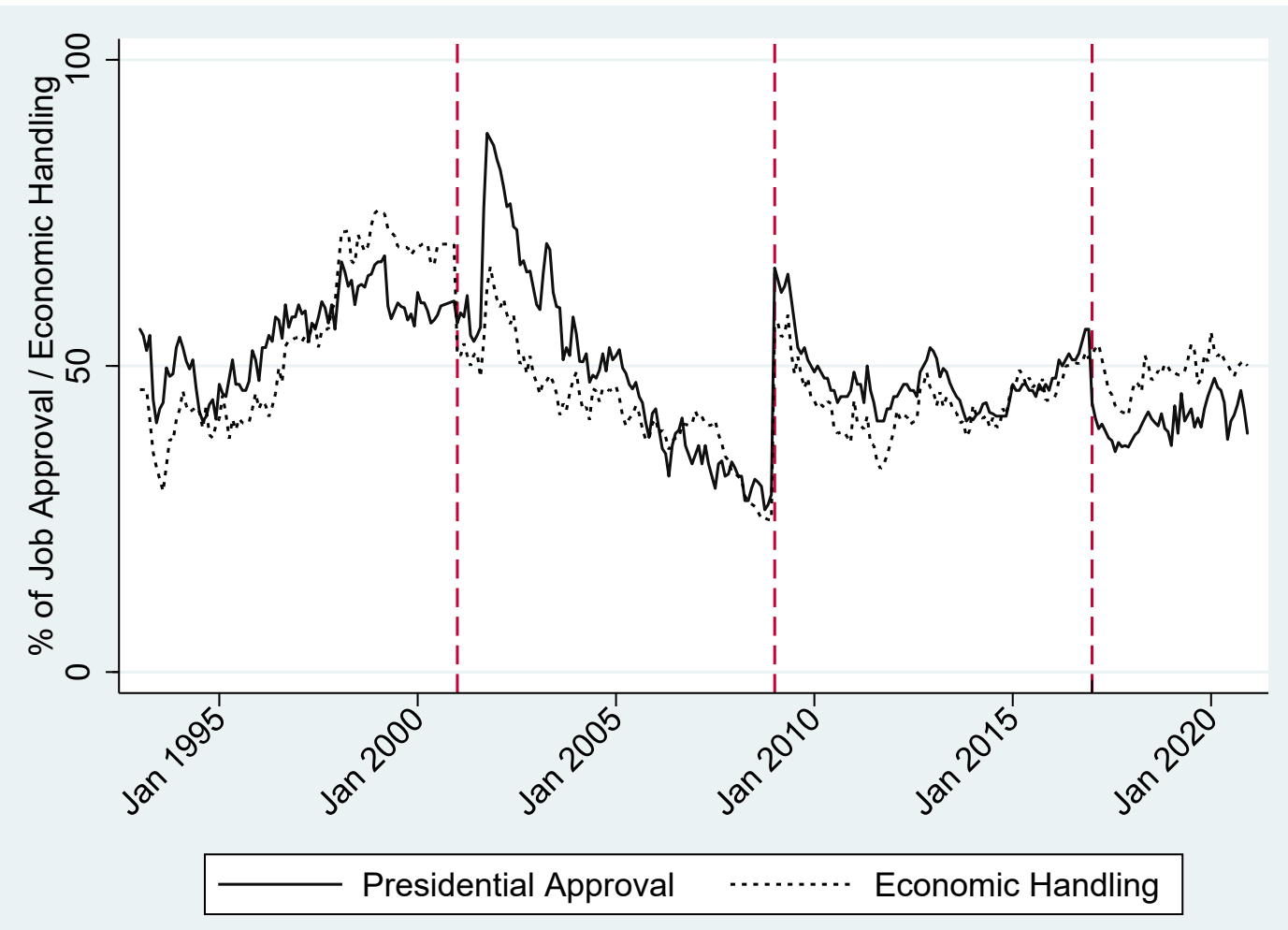


Figure 2: Impact of Composite Variables on Presidential Approval
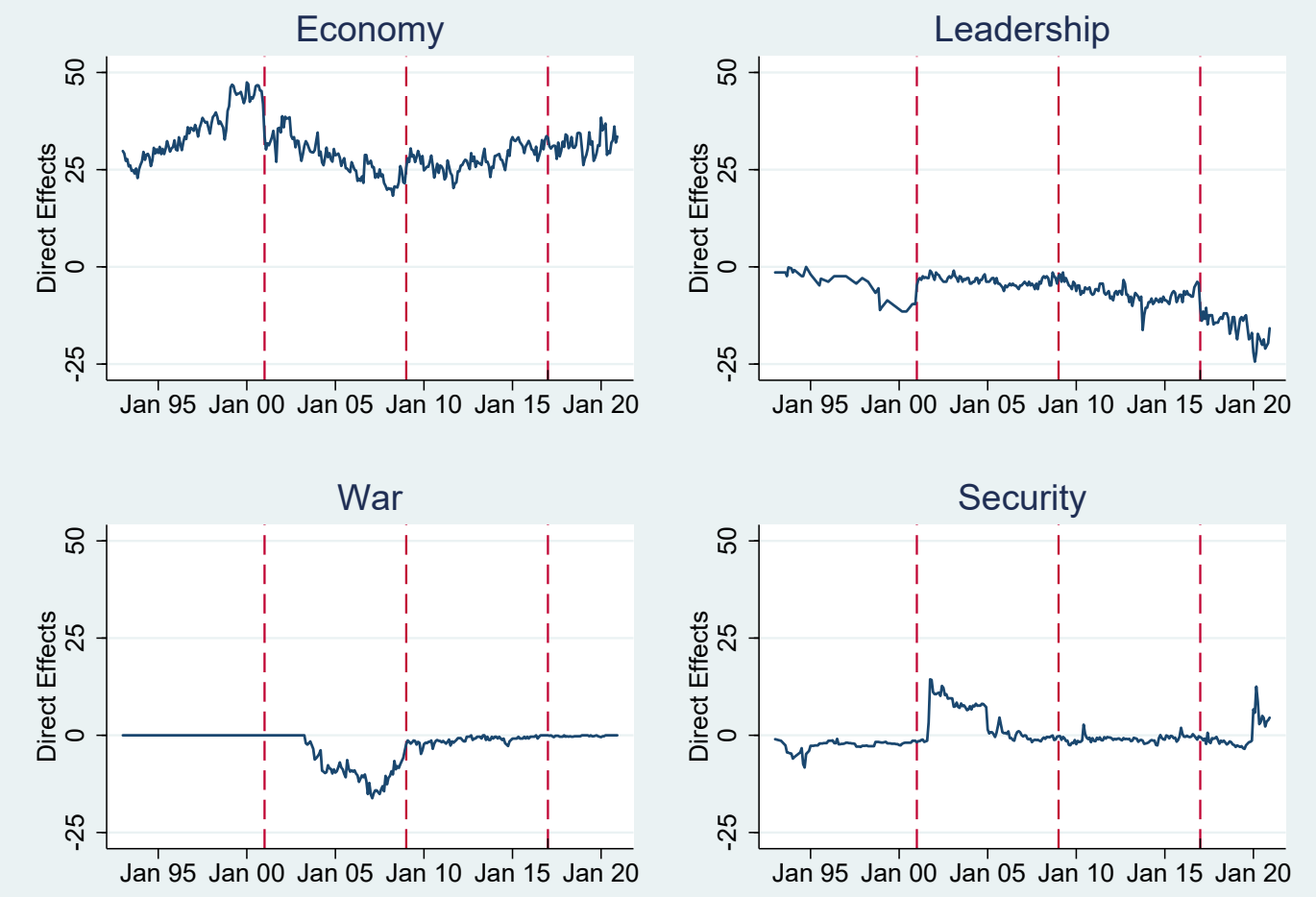


\section{Appendices}

\section{Appendix A}

Table A1: Information on Variables - Part 1

\begin{tabular}{|c|c|c|c|}
\hline & Name & Measurement & Data Source \\
\hline \multicolumn{4}{|c|}{ Endogenous Variables } \\
\hline At & Job Approval & Average Monthly Approval & http://www.gallup.com/poll/ \\
\hline$E t$ & Economic Handling & $\begin{array}{l}\text { Approval of President's Handling } \\
\text { of the Economy }\end{array}$ & See discussion for how constructed \\
\hline \multicolumn{4}{|c|}{ Environmental Variables } \\
\hline$X 1 t$ & Leadership Concerns & $=1$ & Always "on" \\
\hline$X 2 t$ & Battle Deaths & $\begin{array}{l}\text { Log10 Cumulative Battle Deathst } \\
; 0 \text { otherwise (nb. Each presidency } \\
\text { begins at zero) }\end{array}$ & http://icasualties.org/Iraq/Index.aspx \\
\hline$X 3 t$ & External Security & $=1$ & \multirow{2}{*}{ Always "on" } \\
\hline$X_{4} t$ & Internal Security & $=1$ & \\
\hline$X 5 t$ & Existential Death & $\begin{array}{l}\text { Log10 Cumulative Deaths ; } 0 \text { oth- } \\
\text { erwise (nb. Lasts until end of cur- } \\
\text { rent term) }\end{array}$ & $\begin{array}{l}\text { https://www.britannica.com/event/ } \\
\text { September-11-attacks } \\
\text { https://en.wikipedia.org/wiki/COVID- } \\
\text { 19_pandemic_deaths }\end{array}$ \\
\hline$X 6 t$ & ICS: Current & Monthly Current Expectations & $\begin{array}{l}\text { http://www.sca.isr.umich.edu/tables. } \\
\text { html }\end{array}$ \\
\hline$X 7 t$ & ICS: Future - Current & Current - Future Expectations & $\begin{array}{l}\text { http://www.sca.isr. umich.edu/tables. } \\
\text { html }\end{array}$ \\
\hline$X 8 t$ & S\&P 500 & Month End Value of S\&P 500 & $\begin{array}{l}\text { http://www.cboe.com/products/stock- } \\
\text { index-options-spx-rut-msci-ftse/ }\end{array}$ \\
\hline \multicolumn{4}{|c|}{ Events } \\
\hline$X 9 t$ & Positive Economic Events & \multirow{2}{*}{$\begin{array}{l}\text { See Table } 1-\text { coded } 1 \text { in all months } \\
\text { with " } 3+\text { days coverage"; } 0 \text { otherwise }\end{array}$} & \multirow{4}{*}{$\begin{array}{l}=1 \text { if covered for at least twenty days in a } \\
\text { month on the front page of the New York } \\
\text { Times }\end{array}$} \\
\hline$X 10 t$ & Negative Economic Events & & \\
\hline$X 11 t$ & Existential Threat & $\begin{array}{l}1 \text { from } 9 / 2001 \text { thru } 12 / 2004 ; 1 \text { from } \\
1 / 2020 \text { to } 3 / 2020 ; 0 \text { otherwise }\end{array}$ & \\
\hline$X 12 t$ & Impeachment & $\begin{array}{l}1 \text { from } 12 / 1998 \text { thru } 12 / 2000 ; 1 \\
\text { from } 1 / 2020 \text { to } 3 / 2020 ; 0 \text { otherwise }\end{array}$ & \\
\hline$X 13 t$ & Positive International & \multirow{4}{*}{$\begin{array}{l}\text { See Table } 1-\text { coded } 1 \text { in all months } \\
\text { with " } 3+\text { days coverage"; } 0 \text { otherwise }\end{array}$} & \multirow{4}{*}{$\begin{array}{l}\text { Events that were covered for at least three } \\
\text { days on the front page of the New York } \\
\text { Times }\end{array}$} \\
\hline$X 14 t$ & Positive Domestic & & \\
\hline$X 15 t$ & Negative International & & \\
\hline$X 16 t$ & Negative Domestic & & \\
\hline
\end{tabular}


Table A2: Information on Variables - Part 2

\begin{tabular}{|c|c|c|c|}
\hline & Name & Measurement & Data Source \\
\hline \multicolumn{4}{|c|}{ Salience Weights } \\
\hline$W 1 t$ & Leadership MIP & "Dissatisfaction with Government" & \multirow{5}{*}{$\begin{array}{l}\text { Monthly Gallup Polls via Roper Center } \\
\text { for Public Opinion Research }\end{array}$} \\
\hline W2t & War MIP & "Situation in Iraq/War" & \\
\hline$W 3 t$ & External Security MIP & $\begin{array}{l}\text { "Terrorism" \& "Diseases/COVID- } \\
19 "\end{array}$ & \\
\hline W4t & Internal Security MIP & $\begin{array}{l}\text { "Crime", "Healthcare" \& "Immi- } \\
\text { gration" }\end{array}$ & \\
\hline$W 5 t$ & Economy MIP & Sum of all economic responses & \\
\hline W6t & Death Concerns & Concerned about External Threats & $\begin{array}{l}\text { https://news.gallup.com/poll/4909/ } \\
\text { terrorism-united-states.aspx } \\
\text { https://projects.fivethirtyeight.com/ } \\
\text { coronavirus-polls/ }\end{array}$ \\
\hline \multicolumn{4}{|c|}{ Environmental Variables (weighted by salience) } \\
\hline$Z 1 t$ & Leadership Concerns & $\mathrm{X} 1 \mathrm{t}^{*} \mathrm{~W} 1 \mathrm{t}$ & \\
\hline$Z 2 t$ & Battle Deaths & $\mathrm{X} 2 \mathrm{t} * \mathrm{~W} 2 \mathrm{t}$ & \\
\hline$Z 3 t$ & External Security & $\mathrm{X} 3 \mathrm{t} * \mathrm{~W} 3 \mathrm{t}$ & \\
\hline$Z 4 t$ & Internal Security & $\mathrm{X} 4 \mathrm{t}^{*} \mathrm{~W} 4 \mathrm{t}$ & \\
\hline$Z 5 t$ & Existential Death & $\mathrm{X} 5 \mathrm{t}^{*} \mathrm{~W} 6 \mathrm{t}$ & \\
\hline$Z 6 t$ & ICS: Current & $\mathrm{X} 6 \mathrm{t} *(1-\mathrm{W} 5 \mathrm{t})$ & \\
\hline$Z 7 t$ & ICS: Future - Current & $\mathrm{X} 7 \mathrm{t}^{*}(1-\mathrm{W} 5 \mathrm{t})$ & \\
\hline$Z 8 t$ & S\&P 500 & $\mathrm{X} 8 \mathrm{t} *(1-\mathrm{W} 5 \mathrm{t})$ & \\
\hline
\end{tabular}




\section{Appendix B - Online}

Table B1: Summary Statistics

\begin{tabular}{|c|c|c|c|c|c|}
\hline Variable & Name & Mean & SD & Min & Max \\
\hline \multicolumn{6}{|c|}{ Endogenous Variables } \\
\hline At & Job Approval & 49.51 & 10.71 & 26.50 & 88.00 \\
\hline Et & Economic Handling & 47.72 & 10.30 & 24.83 & 75.42 \\
\hline \multicolumn{6}{|c|}{ Environmental Variables (weighted by salience) } \\
\hline Z1t & Leadership Concerns & 12.20 & 8.42 & 0.00 & 1.00 \\
\hline $\mathrm{Z} 2 \mathrm{t}$ & Battle Deaths & 0.18 & 0.33 & 0.00 & 1.35 \\
\hline Z3t & External Security & 4.88 & 8.05 & 0.00 & 46.00 \\
\hline $\mathrm{Z} 4 \mathrm{t}$ & Internal Security & 18.52 & 10.04 & 2.00 & 83.00 \\
\hline $\mathrm{Z} 5 \mathrm{t}$ & Existential Death & 0.09 & 0.30 & 0.00 & 1.90 \\
\hline Z6t & ICS: Current & 74.02 & 23.93 & 18.98 & 113.93 \\
\hline $\mathrm{Z7t}$ & ICS: Future - Current & 14.53 & 6.61 & -0.65 & 30.46 \\
\hline $\mathrm{Z} 8 \mathrm{t}$ & S\&P 500 & 10.92 & 7.33 & 1.84 & 34.93 \\
\hline \multicolumn{6}{|l|}{ Events } \\
\hline X9t & Positive Economic Events & 0.05 & 0.21 & 0.00 & 1.00 \\
\hline $\mathrm{X} 10 \mathrm{t}$ & Negative Economic Events & 0.18 & 0.38 & 0.00 & 1.00 \\
\hline $\mathrm{X} 11 \mathrm{t}$ & Existential Attack & 0.15 & 0.36 & 0.00 & 1.00 \\
\hline $\mathrm{X} 12 \mathrm{t}$ & Impeachment & 0.11 & 0.31 & 0.00 & 1.00 \\
\hline $\mathrm{X} 13 \mathrm{t}$ & Positive International & 0.14 & 0.35 & 0.00 & 1.00 \\
\hline $\mathrm{X} 14 \mathrm{t}$ & Positive Domestic & 0.07 & 0.25 & 0.00 & 1.00 \\
\hline $\mathrm{X} 15 \mathrm{t}$ & Negative International & 0.07 & 0.25 & 0.00 & 1.00 \\
\hline $\mathrm{X} 16 \mathrm{t}$ & Negative Domestic & 0.22 & 0.42 & 0.00 & 1.00 \\
\hline
\end{tabular}


Table B2: Ordinary Political Events - Part 1

\begin{tabular}{|c|c|c|c|}
\hline Number & Date & Ordinary Political Events & Duration \\
\hline 1 & Jan-93 & Navy launches missile at Iraq (PI) & 1 \\
\hline 2 & Feb-93 & World Trade Center Bombing (ND) & 7 \\
\hline 3 & Sep-93 & Rabin-Arafat sign accord (PI) & 1 \\
\hline 4 & Nov-94 & Contract with America (ND) & 3 \\
\hline 5 & Feb-95 & Surgeon general under fire (ND) & 2 \\
\hline 6 & Apr-95 & Oklahoma City Bombing (PD) & 4 \\
\hline 7 & Dec-95 & Govt Shutdown (ND) & 2 \\
\hline 8 & Dec-95 & Bosnia Situation (PI) & 7 \\
\hline 9 & Jul-96 & Khobar Tower (PI) & 1 \\
\hline 10 & Aug-96 & Olympic Bombing (ND) & 1 \\
\hline 11 & Sep-96 & US missile attack on Iraq (PI) & 1 \\
\hline 12 & Feb-98 & Saddam backs down agrees with UN (PI) & 1 \\
\hline 13 & Feb-98 & Lewinsky Scandal (ND) & 9 \\
\hline 14 & Aug-98 & Kenya/Tanzania bombings (PI) & 3 \\
\hline 15 & Mar-99 & Kosovo (NI) & 6 \\
\hline 16 & Nov-00 & USS Cole (PI) & 1 \\
\hline 17 & Feb-01 & US and UK Planes Attack Iraq (PI) & 1 \\
\hline 18 & Apr-01 & US Spy Plane collides with Chinese Fighter Jet (PI) & 1 \\
\hline 19 & Jan-02 & Invasion of Afghanistan (PI) & 1 \\
\hline 20 & Mar-03 & Invasion of Iraq (PI) & 7 \\
\hline 21 & Sep-03 & No WMDs (PI) & 3 \\
\hline 22 & Oct-03 & No WMDs (ND) & 1 \\
\hline 23 & Dec-03 & Saddam captured (PI) & 2 \\
\hline 24 & Apr-04 & Abu Ghraib (NI) & 4 \\
\hline 25 & Feb-05 & Iraqui popular vote $(\mathrm{PI})$ & 3 \\
\hline 26 & Sep-05 & Katrina (PD and ND) & 2 \\
\hline 27 & Nov-05 & Libby Indicted (ND) & 1 \\
\hline 28 & Mar-06 & Katrina Congressional Investigation (ND) & 3 \\
\hline 29 & Feb-07 & Iraq Surge $(\mathrm{PI})$ & 2 \\
\hline 30 & Jun-07 & Bush Claims Executive Privilege; Libby (ND) & 2 \\
\hline 31 & Mar-08 & Rescind ban on waterboarding (NI) & 1 \\
\hline 32 & Apr-09 & Navy Seals rescue Captain Phillips (PI) & 1 \\
\hline
\end{tabular}


Table B3: Ordinary Political Events - Part 2

\begin{tabular}{|c|c|c|c|}
\hline Number & Date & Ordinary Political Events & Duration \\
\hline 33 & Jun-09 & Obama Speech in Cairo (PI) & 1 \\
\hline 34 & Dec-09 & Surge in Iraq $(\mathrm{PI})$ & 1 \\
\hline 35 & Mar-10 & Affordable Care Act (PD) & 1 \\
\hline 36 & May-10 & BP Oil Spill (ND) & 1 \\
\hline 37 & Dec-10 & Repeal DADT (PD) & 2 \\
\hline 38 & Jan-11 & Gabby Giffords attack (PD) & 2 \\
\hline 39 & Feb-11 & Arab Spring (PI) & 2 \\
\hline 40 & May-11 & Bin Laden Killed (PI) & 3 \\
\hline 41 & Oct-12 & Hurricane Sandy (PD) & 2 \\
\hline 42 & Dec-12 & Sandy Hook Shooting (PD) & 2 \\
\hline 43 & Mar-13 & Sequestration $(\mathrm{PD})$ & 2 \\
\hline 44 & Apr-13 & Boston Marathon Bombing (PD) & 2 \\
\hline 45 & Oct-13 & Government Shutdown (PD) & 3 \\
\hline 46 & Mar-14 & Russia Annexes Crimea (PI) & 1 \\
\hline 47 & Jun-14 & Rise of ISIS (NI) & 1 \\
\hline 48 & Aug-14 & Michael Brown shooting in Ferguson (ND) & 1 \\
\hline 49 & Jun-15 & Charleston Church Shooting (ND) & 3 \\
\hline 50 & Jun-15 & Same Sex Marriage Decision (PD) & 1 \\
\hline 51 & Jan-16 & Flint Water Crisis (ND) & 2 \\
\hline 52 & Jun-16 & Orlando Terror Attack (ND) & 1 \\
\hline 53 & Mar-17 & Immigration Executive Order; Flynn Resigns (ND) & 2 \\
\hline 54 & May-17 & Comey Fired; Mueller Hired (ND) & 3 \\
\hline 55 & Jun-17 & Withdrawal from Paris Accords (NI) & 2 \\
\hline 56 & Aug-17 & Charlottesville (ND) & 5 \\
\hline 57 & Dec-17 & Recognizing Jerusalem as Capitol (PI) & 1 \\
\hline 58 & Jan-18 & Government Shutdown (ND) & 4 \\
\hline 59 & May-18 & US leaves Iran Nuclear Deal (NI) & 2 \\
\hline 60 & Jun-18 & North Korean Summit (PI) & 1 \\
\hline 61 & Jul-18 & Helsinki Meeting with Putin (ND) & 1 \\
\hline 62 & Oct-18 & Murder of Jamal Khashoggi (NI) & 3 \\
\hline 63 & Nov-18 & Ukraine Crisis (NI) & 3 \\
\hline 64 & Apr-19 & Mueller Report Released (ND) & 1 \\
\hline 65 & Jan-19 & China Tensions Huwei (NI) & 1 \\
\hline 66 & Sep-19 & Whistleblower Report (ND) & 1 \\
\hline
\end{tabular}


Table B4: Ordinary Political Events - Part 3

\begin{tabular}{|c|c|l|c|}
\hline Number & Date & Ordinary Political Events & Duration \\
\hline 67 & Oct-19 & Impeachment Hearings Begin in House (ND) & 3 \\
\hline 68 & Jan-20 & Drone Strike in Iran (PI) & 1 \\
\hline 69 & Feb-20 & Trump Acquitted in Senate (PD) & 1 \\
\hline 70 & Mar-20 & WHO Declares Pandemic COVID (NI) & 3 \\
\hline 71 & May-20 & George Floyd Death and Protests (ND) & 3 \\
\hline 72 & Aug-20 & 3rd Arab Israel Peace (PI) & 1 \\
\hline 73 & Aug-20 & Wildfires in West (ND) & 1 \\
\hline 74 & Sep-20 & Justice Ginsburg Dies (ND) & 3 \\
\hline 75 & Nov-20 & US Exits Paris Agreements (NI) & 1 \\
\hline
\end{tabular}


Table B5: Ordinary Economic Events

\begin{tabular}{|c|c|c|c|}
\hline Number & Date & Ordinary Economic Events & Duration \\
\hline 1 & Nov-93 & NAFTA passes (NE) & 2 \\
\hline 2 & Nov-94 & Tequila Crisis 1994 (NE) & 3 \\
\hline 3 & Oct-97 & Asia Crisis 1997-8 (NE) & 4 \\
\hline 4 & Mar-99 & Dow Hits $10,000(\mathrm{PE})$ & 3 \\
\hline 5 & Nov-99 & WTO Protests in Seattle (NE) & 2 \\
\hline 6 & Mar-00 & DOTCOM Bubble (NE) & 3 \\
\hline 7 & Feb-01 & Recession 2001 (NE) & 7 \\
\hline 8 & Nov-07 & Recession 2008-09 (NE) & 10 \\
\hline 9 & Sep-08 & Stock Market Crash 2008 (NE) & 4 \\
\hline 10 & Feb-09 & American Recovery and Reinvestment Act (PE) & 3 \\
\hline 11 & Jan-10 & European Debt Crisis (NE) & 1 \\
\hline 12 & Aug-10 & China Becomes Second Biggest Economy (NE) & 1 \\
\hline 13 & Mar-11 & Japan Tsunami and Nuclear Meltdown (NE) & 2 \\
\hline 14 & Sep-11 & Occupy Wall Street (NE) & 5 \\
\hline 15 & Jan-14 & ACA registration begins $(\mathrm{PE})$ & 3 \\
\hline 16 & Jun-16 & BREXIT (NE) & 1 \\
\hline 17 & Sep-17 & Hurricane Harvey (NE) & 2 \\
\hline 18 & Jan-18 & Tax Cuts Take Effect (PE) & 3 \\
\hline 19 & Mar-18 & US China Trade War Begins (NE) & 1 \\
\hline 20 & Sep-18 & Unemployment Hits Record Low (PE) & 3 \\
\hline 21 & Oct-18 & NAFTA to USMCA (PE) & 2 \\
\hline 22 & Jan-19 & US Government Shutdown (NE) & 2 \\
\hline 23 & Mar-19 & Boeing 737 Crashes-Boeing Grounds Planes (NE) & 1 \\
\hline 24 & Aug-19 & Hong Kong Protests (NE) & 2 \\
\hline 25 & Feb-20 & Stock Market Crash (NE) & 1 \\
\hline 26 & Mar-20 & Global Recession (NE) & 4 \\
\hline 27 & Apr-20 & Oil Prices Hit Record Low (NE) & 1 \\
\hline
\end{tabular}




\section{Appendix C - Online}

Table C1 shows how salience has varied over this 28-year period, presenting the minimum and maximum values for each salience type for each presidency. The Table shows considerable variation across and within administrations. During Clinton's tenure, the public paid attention to the economy, internal security, and leadership concerns. During the Bush tenure, the public focused on the economy, external security, internal security, and war. During the Obama administration, the public focused primarily on the economy, leadership concerns, and internal security. During the Trump administration, the public focused primarily on leadership concerns, internal security, and fear of death from external threat with the economy coming in fourth. Figure $\mathrm{C} 1$ further shows variation in MIP over time, showing the percentage citing each environmental factor. Looking down the panels at each presidency shows that each administration had a different set of salient environmental events and conditions. Note in particular that the Trump presidency is unique in that the economy was less salient while institutional integrity and internal security were more salient than usual.

Table C1: Public Salience for Environmental Variable Categories

\begin{tabular}{lccccccccc}
\multirow{2}{*}{ Salience Type } & \multicolumn{2}{c}{ Clinton } & \multicolumn{2}{c}{ Bush } & \multicolumn{2}{c}{ Obama } & \multicolumn{2}{c}{ Trump } \\
\cline { 2 - 9 } & Min & Max & Min & Max & Min & Max & Min & Max \\
\hline Economy & 6 & 58 & 9 & 69 & 16 & 71 & 4 & 19 \\
War & 0 & 0 & 0 & 38 & 0 & 15 & 0 & 3 \\
External Security & 0 & 6 & 0 & 46 & 0 & 19 & 0 & 13 \\
Internal Security & 10 & 83 & 2 & 27 & 2 & 28 & 11 & 35 \\
Leadership Concerns & 0 & 14 & 2 & 13 & 3 & 34 & 22 & 39 \\
Fear of Death from External Threat & 0 & 0 & 0 & 19 & 0 & 0 & 0 & 36
\end{tabular}


Figure C1: Variations in Most Important Issues for Clinton/Bush/Obama/Trump
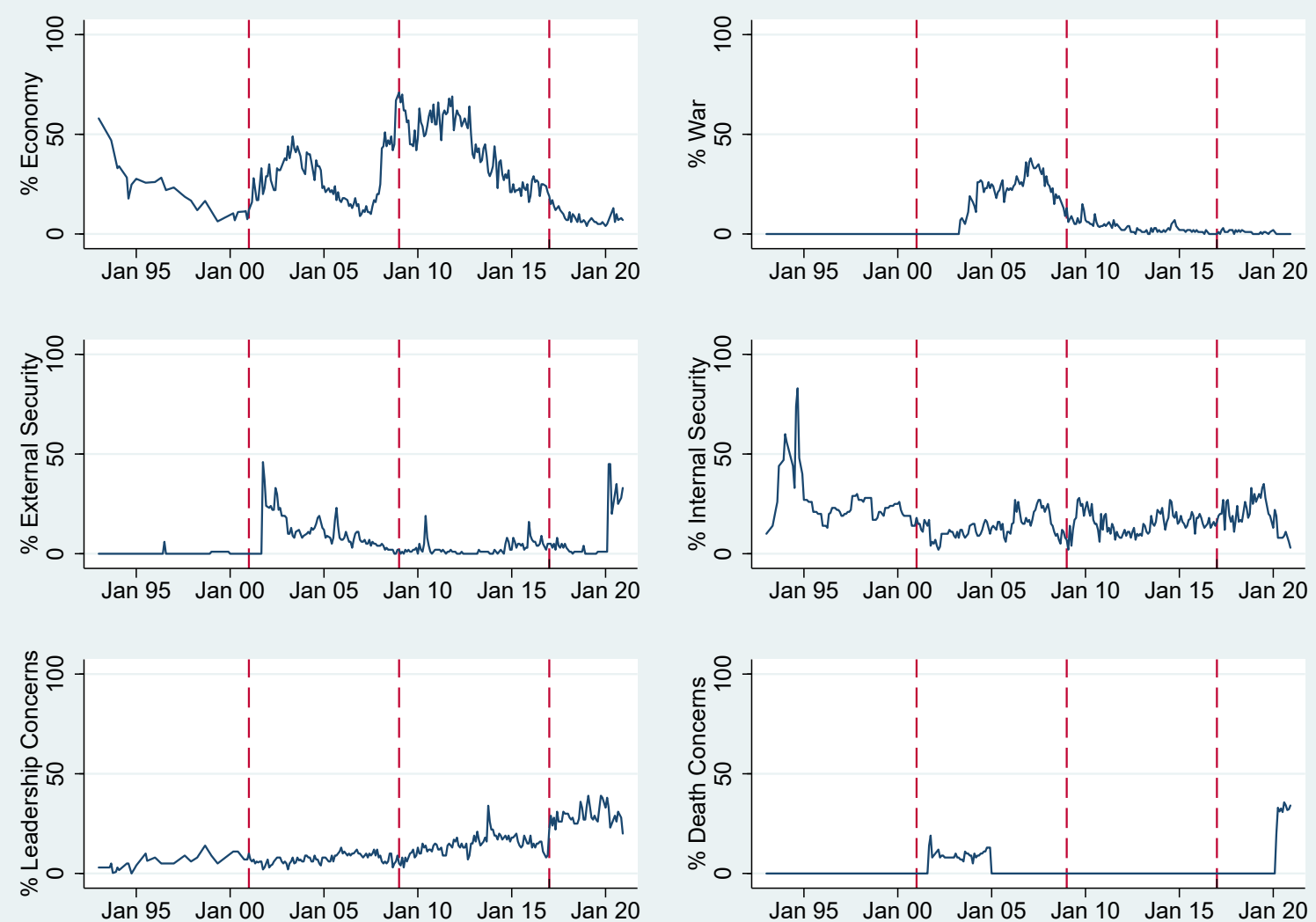


\section{Appendix D - Online}

\section{The Structural Equations}

Using the notation from Tables A1 and A2, the two structural equations of our theoretical model, consisting of two endogenous variables and 15 exogenous variables, are specified as follows [NOTE: These equations are corrected]:

$$
\begin{aligned}
A_{t}= & \beta_{10}+\gamma_{11} E_{t}+\beta_{11} Z_{1 t}+\beta_{12} Z_{2 t}+\beta_{13} Z_{3 t}+\beta_{14} Z_{4 t}+\beta_{15} Z_{5 t}+\beta_{111} X_{11 t} \\
& +\beta_{112} X_{12 t}+\beta_{113} X_{13 t}+\beta_{114} X_{14 t}+\beta_{115} X_{15 t}+\beta_{116} X_{16 t}+\mu_{1 t} \\
E_{t}= & \beta_{20}+\gamma_{21} A_{t}+\beta_{25} Z_{5 t}+\beta_{26} Z_{6 t}+\beta_{27} Z_{7 t}+\beta_{28} Z_{8 t}+\beta_{29} X_{9 t} \\
& +\beta_{210} X_{10 t}+\beta_{211} X_{11 t}+\beta_{212} X_{12 t}+\mu_{2 t}
\end{aligned}
$$

As presented in Tables A1 and A2, the use of "Z" variables indicates that the underlying indicator is weighted by its monthly salience score.

\section{Specifying the Baseline Models}

In order to assess the validity of the basic model specified in Equations 1 and 2, we propose three alternative models. First, we remove salience from the basic model by replacing the Z variables with their X counterparts. Since $X_{1 t}, X_{3 t}$, and $X_{4 t}$ are all equal to 1 due to the fact that the public is constantly monitoring the environment on these issues and since salience is being removed, the three variables have no variation and hence become part of the estimated constant term in the approval equation. Hence, the baseline No Salience model is as follows: 


$$
\begin{aligned}
A_{t}= & \beta_{30}+\gamma_{31} E_{t}+\beta_{32} X_{2 t}+\beta_{35} X_{5 t}+\beta_{311} X_{11 t}+\beta_{312} X_{12 t} \\
& +\beta_{313} X_{13 t}+\beta_{314} X_{14 t}+\beta_{315} X_{15 t}+\beta_{316} X_{16}+\mu_{3 t} \\
E_{t}= & \beta_{20}+\gamma_{41} A_{t}+\beta_{45} X_{5 t}+\beta_{46} X_{6 t}+\beta_{47} X_{7 t}+\beta_{48} X_{8 t} \\
& +\beta_{49} X_{9 t}+\beta_{410} X_{10 t}+\beta_{411} X_{11 t}=\beta_{412} x_{12}+\mu_{4 t}
\end{aligned}
$$

To remove the mediating influence of economic approval, we can solve for the reduced form which characterizes approval and economic approval respectively as a function of all of the exogenous variables in the system. When we leave salience in the model, the baseline $N_{0}$ Economic Handling model is as follows:

$$
\begin{aligned}
A_{t}= & \pi_{50}+\pi_{51} Z_{1 t}+\pi_{52} Z_{2 t}+\pi_{53} Z_{3 t}+\pi_{54} Z_{4 t}+\pi_{55} Z_{5 t}+\pi_{56} Z_{6 t}+\pi_{57} Z_{7 t}+\pi_{58} Z_{8 t} \\
& +\pi_{59} X_{9 t}+\pi_{510} X_{10 t}+\pi_{511} X_{11 t}+\pi_{512} X_{12 t}+\pi_{513} X_{13 t}+\pi_{514} X_{14 t} \\
& +\pi_{515} X_{15 t}+\pi_{516} X_{16}+\mu_{5 t} \\
E_{t}= & \pi_{60}+\pi_{61} Z_{1 t}+\pi_{62} Z_{2 t}+\pi_{63} Z_{3 t}+\pi_{64} Z_{4 t}+\pi_{65} Z_{5 t}+\pi_{66} Z_{6 t}+\pi_{67} Z_{7 t}+\pi_{68} Z_{8 t} \\
& +\pi_{69} X_{9 t}+\pi_{610} X_{10 t}+\pi_{611} X_{11 t}+\pi_{612} X_{12 t}+\pi_{613} X_{13 t}+\pi_{614} X_{14 t} \\
& +\pi_{615} X_{15 t}+\pi_{616} X_{16}+\mu_{6 t}
\end{aligned}
$$

For the final baseline comparison, it is possible to have a model that omits both salience and the mediating impact of economic handling by replacing the $\mathrm{Z}$ variables with their $\mathrm{X}$ counterparts and by using the reduced form equation for both endogenous variables. This leads to the following $N o$ Salience/No Endogeneity. It is important to note that $X_{1 t}, X_{3 t}$, and 
$X_{4 t}$ are all constant terms without the salience weighting as can be seen in Tables A1 and A2. As such, they are dropped from the model and their impact is captured by the constant term.:

$$
\begin{aligned}
A_{t}= & \pi_{70}+\pi_{72} X_{2 t}+\pi_{75} X_{5 t}+\pi_{76} X_{6 t}+\pi_{77} X_{7 t}+\pi_{78} X_{8 t}+\pi_{79} X_{9 t}+\pi_{711} X_{11 t} \\
& +\pi_{712} X_{12 t}+\pi_{713} X_{13 t}+\pi_{714} X_{14 t}+\pi_{715} X_{15 t}+\pi_{716} X_{16}+\mu_{7 t} \\
E_{t}= & \pi_{80}+\pi_{82} X_{2 t}+\pi_{85} X_{5 t}+\pi_{86} X_{6 t}+\pi_{87} X_{7 t}+\pi_{88} X_{8 t}+\pi_{89} X_{9 t}+\pi_{810} X_{10 t}+\pi_{811} X_{11 t} \\
& +\pi_{812} X_{12 t}+\pi_{813} X_{13 t}+\pi_{814} X_{14 t}+\pi_{815} X_{15 t}+\pi_{816} X_{16}+\mu_{8 t}
\end{aligned}
$$

Having specified the two sets of base lines models, it is possible to consider the various

\begin{tabular}{|c|c|c|}
\hline & No Salience & Salience \\
\hline \multicolumn{3}{|l|}{ Presidential Approval } \\
\hline$\overline{\text { No Economic Handling }}$ & Eq. 7 & Eq. 5 \\
\hline Include Economic Handling & Eq. 3 & Eq. 1 \\
\hline \multicolumn{3}{|l|}{ Economic Handling } \\
\hline No Presidential Approval & Eq. 8 & Eq. 6 \\
\hline Include Presidential Approval & Eq. 4 & Eq. 2 \\
\hline
\end{tabular}
comparisons that can be made to test the baseline hypotheses. Table D1 provides a tabular view of the possible comparisons that are made in the text.

Table D1: Description of the Model Comparisons

\section{Testing the Alternative Models}

To compare our structural equations [Equations 1 and 2] to the alternative models, we use both the Akaike Information Criterion (AIC) and the Bayesian Information Criterion (BIC). 
These two criteria provide a means to compare different models that balances the drawbacks of both under- and over-fitting (see Appendix C for details). The lower the AIC/BIC relative to other models, the better the model performs. Table D2 shows that, for the approval equations, in every case including salience provides a better fit than ignoring salience (the $\mathrm{AIC} / \mathrm{BIC}$ in the salience columns is lower than in the no salience columns). In addition, in every case, including economic handling provides a better fit than not including economic handing (AICs/BICs are lower in the rows with economic handling than those without it). Including both salience and economic handling fits the data the best of all, by a substantial margin. We find identical results in terms of the Economic Handling equation. The evidence is clear and convincing: the models that include salience and Economic Handling outperform models that do not include one or both of these factors. When taken together with the earlier finding of endogneity between Approval and Economic Handling, it is clear that the basic pillars of our model have strong empirical support.

Table D2: AIC and BIC for Salience and Endogeneity Comparisons

AIC BIC

No Salience Salience No Salience Salience

\begin{tabular}{lcccc}
\hline Presidential Approval & & & & \\
No Economic Handling & 2250.18 & 2063.72 & 2303.62 & 2120.98 \\
Include Economic Handling & 2074.12 & $\mathbf{1 7 1 7 . 5 2}$ & 2112.29 & $\mathbf{1 7 6 7 . 1 5}$ \\
\hline Economic Handling & & & & \\
No Presidential Approval & 2118.15 & 2040.67 & 2171.59 & 2104.96 \\
Include Presidential Approval & 1834.62 & $\mathbf{1 7 6 3 . 6 4}$ & 1872.79 & $\mathbf{1 8 0 1 . 8 1}$
\end{tabular}




\section{Appendix E - Online}

\section{Specifying the Reduced Form}

The reduced form equations are obtained by solving the structural equations (Appendix D, equations (1) and (2)), so that each endogenous variable is expressed as a function of the exogenous variables:

$$
\begin{aligned}
A_{t}= & {\left[\frac{1}{1-\gamma_{11} \gamma_{21}}\right]\left[\left(\beta_{10}+\gamma_{11} \beta_{20}\right)+\beta_{11} Z_{1 t}+\beta_{12} Z_{2 t}+\beta_{13} Z_{3 t}+\beta_{14} Z_{4 t}\right.} \\
& +\left(\gamma_{11} \beta_{25}+\beta_{15}\right) Z_{5 t}+\gamma_{11} \beta_{26} Z_{6 t}+\gamma_{11} \beta_{27} Z_{7 t}+\gamma_{11} b_{28} Z_{8 t}+\gamma_{11} \beta_{29} X_{9 t} \\
& +\gamma_{11} \beta_{210} X_{10 t}+\left(\gamma_{11} \beta_{211}+\beta_{111}\right) X_{11 t}+\left(\gamma_{11} \beta_{212}+\beta_{112}\right) X_{12 t}+\beta_{113} X_{13 t} \\
& \left.+\beta_{114} X_{14 t}+\beta_{115} X_{15 t}+\beta_{116} X_{16 t}+\left(\mu_{1 t}+\gamma_{11} \mu_{2 t}\right)\right] \\
E_{t}= & {\left[\frac{1}{1-\gamma_{11} \gamma_{21}}\right]\left[\left(\beta_{20}+\gamma_{21} \beta_{10}\right)+\gamma_{21} \beta_{11} Z_{1 t}+\gamma_{21} \beta_{12} Z_{2 t}+\gamma_{21} b_{13} Z_{3 t}\right.} \\
& +\gamma_{21} \beta_{14} Z_{4 t}+\left(\gamma_{21} \beta_{15}+\beta_{25}\right) Z_{5 t}+\beta_{26} Z_{6 t}+\beta_{27} Z_{7 t}+\beta_{28} Z_{8 t}+\beta_{29} X_{9 t} \\
& +\beta_{210} X_{10 t}+\left(\gamma_{21} \beta_{111}+\beta_{211}\right) X_{11 t}+\left(\gamma_{21} \beta_{112}+\beta_{212}\right) X_{12 t}+\gamma_{21} \beta_{113} X_{13 t} \\
& \left.+\gamma_{21} \beta_{114} X_{14 t}+\gamma_{21} \beta_{115} X_{15 t}+\gamma_{21} \beta_{116} X_{16 t}+\left(\mu_{2 t}+\gamma_{21} \mu_{1 t}\right)\right]
\end{aligned}
$$

Note that the directly estimated reduced form equations are identical to Equations (5) and (7) in Appendix D. In the case of the Approval reduced form equation, these are the results one would obtain if one were to ignore the impact of Economic Handling on Approval. 


\section{Reciprocal Relationship}

To assess the impact of the reciprocal relationship between Presidential Approval and Economic Handling, we turn to the derived reduced form equations which are obtained by solving the structural equations (Equations 1 and 2 in Appendix D) so that each endogenous variable is expressed as a function of all of the exogenous variables in the entire model. The derived reduced form coefficients are presented in Table E1 (see Appendix D for details) and show the implied impacts of each exogenous variable based on the estimates from the structural equations. The derived reduced form coefficients indicate how the path of the exogenous variables influences the short-term behavior of the endogenous variables based upon the restrictions in the structural equations. As such, it provides a measure of the total (direct and indirect) effect of each exogenous variable on each of the endogenous variables.

In the derived reduced form equations, the weight ${ }^{16}$ represents the amplification that results from the reciprocal relationship between approval and economic handling. Substituting the estimated values shows that the impact of each exogenous variable is amplified by over $47 \%$ as a result of the reciprocal relationship. For example, a one-unit increase in the weighted battle death measure leads to a direct drop of -11.99 points and an indirect impact of -5.68 points for a total impact of -17.67. A similar argument can be made with respect to leadership concerns-a one-unit increase in institutional integrity (the variable theoretically ranges from 0-100) leads to a direct drop of -.47 points and an indirect impact of -.23 points for a total impact of -.70. For those factors that have a negative impact on approval, this relationship has the potential to be quite "vicious".

Three variables — Existential Threat, Deaths from External Threat, and Impeachment - appear in both structural equations. The reduced form provides some insight into two interesting implications. First, the coefficients for the extraordinary events have opposite 
Table E1: Derived and Directly Estimated Reduced Form

Derived RF Coefficients Direct RF Coefficients

\begin{tabular}{lrrrr}
\hline $\begin{array}{l}\text { Exogenous } \\
\text { Variable }\end{array}$ & $\begin{array}{c}\text { Job } \\
\text { Approval }\end{array}$ & $\begin{array}{c}\text { Economic } \\
\text { Handling }\end{array}$ & $\begin{array}{c}\text { Job } \\
\text { Aprroval }\end{array}$ & $\begin{array}{c}\text { Economic } \\
\text { Handling }\end{array}$ \\
\hline Battle Deaths & -17.47 & -8.91 & -16.96 & -8.93 \\
Internal Security & -0.15 & -0.07 & -0.18 & -0.14 \\
External Security & 0.35 & 0.18 & 0.37 & 0.19 \\
Existential Threat & 7.83 & 0.12 & 7.11 & -0.36 \\
Deaths from External Attack & -10.66 & -7.90 & -9.72 & -7.60 \\
Leadership Concerns & -0.71 & -0.36 & -0.43 & -0.13 \\
Impeachment & -1.14 & 7.95 & -0.05 & 8.64 \\
Positive International & 2.77 & 1.41 & 1.83 & 0.15 \\
Negative International & -4.15 & -2.11 & -2.16 & 0.81 \\
Positive Domestic & 2.80 & 1.43 & 0.59 & -0.90 \\
Negative Domestic & -4.17 & -2.13 & -2.50 & -0.11 \\
ICS: Current & 0.22 & 0.35 & 0.25 & 0.38 \\
ICS: Future - Current & -0.54 & -0.85 & -0.58 & -0.88 \\
S\&P 500 & 0.22 & 0.34 & -0.22 & -0.05 \\
Positive Economic & 2.85 & 4.46 & 2.48 & 3.84 \\
Negative Economic & -1.62 & -2.53 & -2.91 & -3.28 \\
Constant & 52.21 & 37.72 & 52.24 & 38.10
\end{tabular}

signs in the two structural equations. Existential Threat has a positive impact on Approval and a negative impact on Economic Handling while the reverse is true for Impeachment. The reduced form provides some insight into the consequences of these findings. Looking first at Existential Threat, we see that the direction of the impact (positive for Approval and negative for Economic Handling) remains the same but the impact is attenuated. Insofar as Impeachment is concerned, the sign changes for Approval although the impact is negligible. Looking at the entire model, Impeachment has a negligible impact on Approval. However, the substantive nuance is much more interesting. It is not that Impeachment does not matter but that it simultaneously raised assessment of Economic Handling while depressing Approval. As 
such, by casting the model in simultaneous equation form, we are able to see the full impact of Impeachment.

It is also possible to directly estimate the reduced form equations by regressing each endogenous variable on all of the exogenous variables in the model. This is, in fact, what happens when economic handling is omitted from the model as we did in Equations 5 and 6 in Appendix D.

The Direct RF estimates are also presented in Table E1. There are two important features of these estimates. First, the Direct and the Derived coefficients are, for the most part, similar to one another in sign and magnitude. One notable exception is that Institutional Integrity has a much larger impact in the Derived than in the Direct RF. Second, the impact of Impeachment becomes positive though statistically insignificant. That is, if one were to estimate a model with only exogenous variables, there would be little evidence that the extraordinary event of an impeachment affects presidential approval. 


\section{Appendix F - Online}

To augment our explanation of presidential approval, we offer one way to understand visually the direct impacts of the economy, war, institutional integrity, and security as filtered through salience and economic handling. To do so, we calculate the estimated impact of four composite variables created from the estimates in Table 1 by multiplying the relevant estimated coefficients from Table 1 by the variables value at time $t$, weighed by salience at time $t$. This yields the following:

- Economic Impact $_{t}=.638 \times \hat{E}_{t}$ where $\hat{E}_{t}$ are predicted values from Economic Handling (i.e., the instrumental variable)

- Security Impact $_{t}=.234 \times Z_{3 t}+7.748 \times X_{11 t}-5.617 \times Z_{5 t}-.099 \times Z_{4 t}$

- War Impact Im $_{t}=-11.785 \times Z_{2 t}$

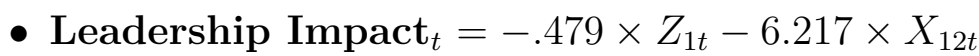


Figure F1: Impact of Composite Variables on each Presidency
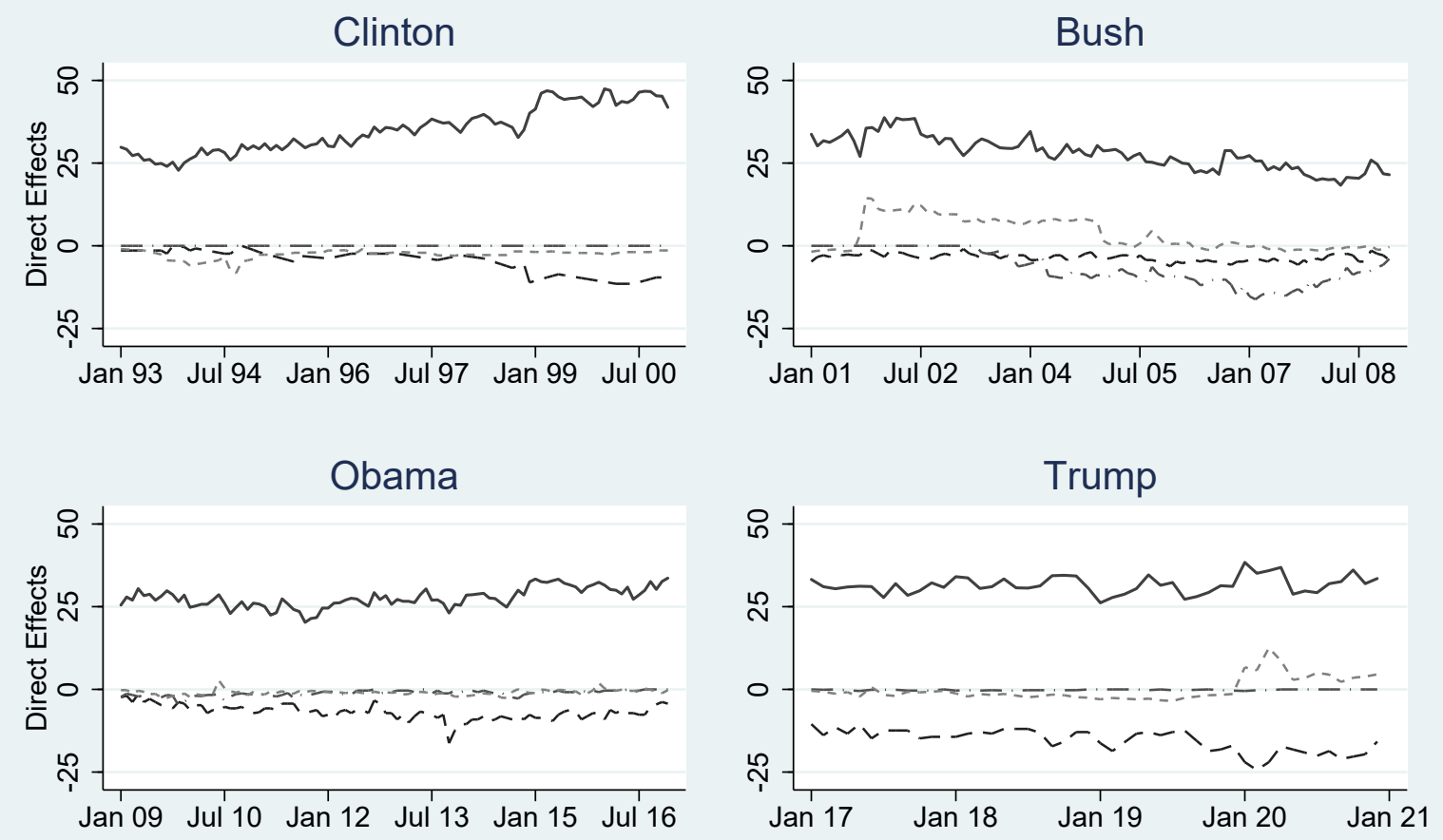

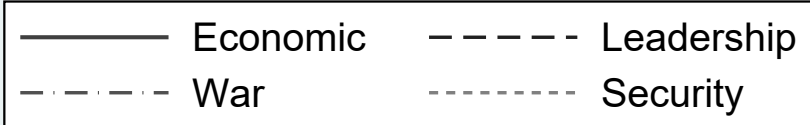

